\author{
Marek Sobczyński
}

\title{
Przemiany zagospodarowania przestrzeni przemyslowej południowej części XIX dzielnicy katastralnej Krakowa-Grzegórzek w XX i XXI wieku na przykladzie zakładów maszynowych Ludwika Zieleniewskiego
}

Zarys treści: W rozdziale zaprezentowano wyniki badań terenowych przeprowadzonych na obszarze fragmentu uprzemysłowionej części XIX dz. kat. Krakowa, czyli na Grzegórzkach, w bloku urbanistycznym wyznaczonym przez dzisiejsze ulice: Grzegórzecką, Kotlarską i Zieleniewskiego oraz nabrzeże Wisły. Ukazane zostały przemiany zagospodarowania przestrzeni, najpierw obszarów podmiejskich, a od pierwszej dekady XX wieku już obszaru miejskiego zagospodarowanego przez zakłady przemysłu metalowo-maszynowego braci Ludwika i Edmunda Zieleniewskich, jedne z najstarszych tej branży w Polsce.

Do zbadania przemian zastosowano szczegółowe terenowe zdjęcie użytkowania ziemi, wykonane metodą zaproponowaną przez zespół Karola Bromka (Bromek, Malinowska, Mydel 1971) w skali 1:1000 przeprowadzone dwukrotnie, w odstępie 44 lat (latojesień 1975 i jesień 2019) (Sobczyński 1976). Uzupełnieniem kartowania w terenie była analiza materiału kartograficznego (mapy topograficzne, zdjęcia lotnicze, ortofotomapa) zarówno z okresu przedinwestycyjnego (koniec XIX w.), jak i z cezur wyznaczonych kolejnymi etapami przemian badanej przestrzeni w okresie przed pierwszym kartowaniem oraz pomiędzy kartowaniami (1975-1999).

Od końca XIX wieku nastąpiła ewolucja użytkowania badanej przestrzeni Krakowa od rolniczego, poprzez przemysłowo-transportowe do rezydencjonalno-rekreacyjnego. Przemiany ustrojowe po 1989 roku nie sprzyjały dalszemu utrzymaniu się na rynku produkcji ciężkiej przemysłu maszynowego i zakłady stopniowo ulegały likwidacji. Przemiany, które nastąpiły w badanym obszarze mają charakter rewolucyjny, zarówno jako przejście na początku XX wieku od przestrzeni ruralnej do przemysłowej, jak i przemiana z początku XXI wieku z ugoru poprzemysłowego do atrakcyjnego architektonicznie i prestiżowego osiedla mieszkaniowego. Musiało to wpłynąć na formy zagospodarowania przestrzeni i sposób użytkowania ziemi na badanym obszarze również w rewolucyjnym wymiarze.

Słowa kluczowe: Kraków, Grzegórzki, Zakłady Zieleniewskiego, użytkowanie ziemi, rewitalizacja obszarów poprzemysłowych. 


\section{Wprowadzenie}

Celem opracowania jest analiza zmian zagospodarowania przestrzeni w południowej części XIX dzielnicy katastralnej Krakowa - Grzegórzek, w okresie od końca XIX wieku aż do jesieni roku 2019. Szczegółowemu badaniu użytkowania ziemi, przy zastosowaniu metody kartowania zaproponowanej przez zespół krakowskiego geografa osadnictwa i ludności Karola Bromka (Bromek, Malinowska, Mydel 1971), poddano blok urbanistyczny położony w kwartale pomiędzy ulicami Kotlarską, Grzegórzecką i Zieleniewskiego oraz północnym brzegiem Wisły. Od początku XX wieku aż do końca pierwszej dekady XXI wieku, większą część tego obszaru zajmowały obiekty przemysłowe rozrastającej się fabryki maszyn i urządzeń braci Zieleniewskich (po II wojnie światowej zakłady im. Szadkowskiego). Do czasu budowy kombinatu stalowego w Nowej Hucie był to jeden z największych krakowskich kompleksów produkcyjnych. Obecnie teren ten pełni niemal wyłącznie funkcję mieszkaniową, a produkcja przemysłowa została stąd całkowicie usunięta.

Przez długie wieki Kraków, będąc stolicą państwowości polskiej, pełnił niemal wyłącznie funkcje administracyjne, handlowe, usługowe i komunikacyjne. Nawet jako ośrodek osadniczy z racji niewielkiej populacji miasta, nie ogrywał wiodącej roli w kraju (w 1815 roku liczył tylko 23 tys. mieszkańców). Funkcja przemysłowa zaczęła się tu rozwijać dość późno, bo pod koniec XIX wieku. Dopiero rozwój przemysłu Krakowa zdynamizował wzrost miasta do 70 tys. mieszkańców w 1890 roku (Chrobaczyński 2004: 67).

W 1850 roku powołano w Krakowie Izbę Handlowo-Przemysłową, ale nie było jeszcze wówczas w mieście żadnego większego zakładu produkcyjnego. Jednym z pierwszych zakładów przemysłowych zlokalizowanych w Krakowie była fabryka maszyn rolniczych wybudowana przez Ludwika Zieleniewskiego w 1851 roku, za czterdziestoletni kredyt pozyskany od Towarzystwa Rolniczo-Przemysłowego (Zawistowski 2001: 7). Głównym fundatorem kredytu był ziemianin z Krzeszowic Adam hr. Potocki, który desygnował 17 tys. złotych reńskich.

Właściciel fabryki Ludwik Zieleniewski był synem kowala Antoniego, który w 1804 roku przybył do Krakowa z Warszawy ${ }^{1}$. Antoni Zieleniewski zatrudnił się w kuźni Pawła Nowakowskiego, położonej prawdopodobnie przy pl. Dominikańskim, a po jego śmierci ożenił się z wdową Marianną, dzięki czemu dostał się do cechu rzemieślniczego. Awans zawodowy pozwolił mu na uruchomienie w 1810 roku własnej kuźni przy ul. św. Marka 31 (róg z ul. św. Krzyża 16) (fot. 1).

${ }^{1}$ Jego brat Michał Zieleniewski był znanym lekarzem balneologiem, założycielem kurortu w Krynicy. 

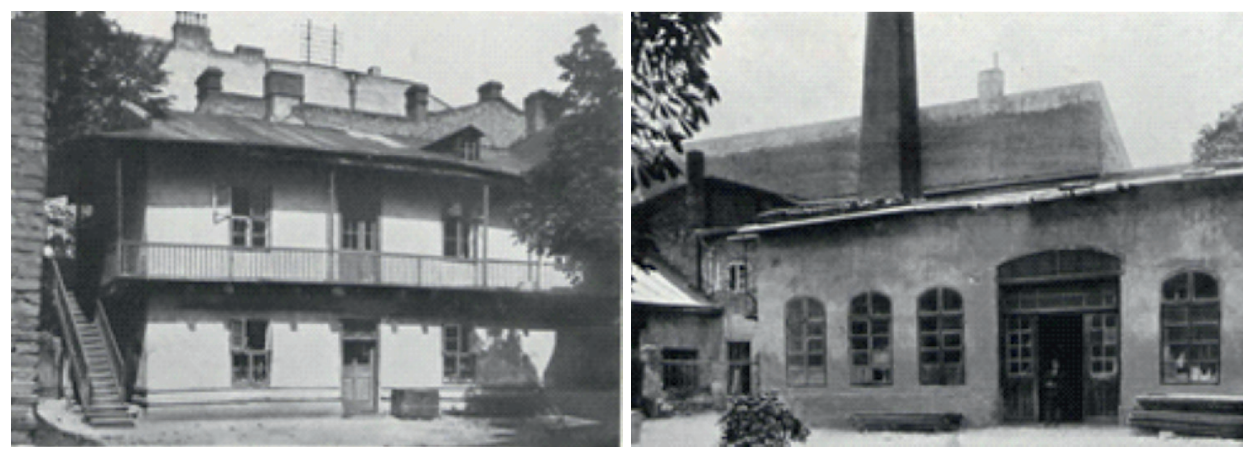

Fot. 1. Biuro fabryki L. Zieleniewskiego w oficynie przy ul. Marka 31 w latach 1850-86; część zabudowań fabrycznych z kominem

Źródło: W. Saryusz-Zaleski (1930: 118)

Antoni Zieleniewski zmarł w 1831 roku i kuźnię przejął jego syn Ludwik, który przekształcił ją w pierwszą krakowską fabrykę produkującą najpierw powozy, a od 1846 roku także maszyny rolnicze. Od 1851 roku zakład funkcjonował pod nazwą Fabryka Narzędzi Gospodarczo-Rolniczych i Machin Przemysłowych, a po 1853 roku nosił nazwę Cesarsko-Królewska Uprzywilejowana Krajowa Fabryka Maszyn Rolniczych i Narzędzi Ludwika Zieleniewskiego. W 1856 roku w zakładach pracowało 56 robotników (Ważniejsze... 2001: 13). Tutaj zainstalowano w 1851 roku pierwszą w mieście maszynę parową, a od 1859 roku zakład dysponował własną odlewnią żelaza (Bąkowski 1932: 171). W 1863 roku zakład L. Zieleniewskiego zatrudniał 40 osób i dysponował tokarkami do obróbki żelaza, brązu, mosiądzu i drewna (Dróżdż, Bradecki, Majewski 1999: 7-8). Po śmierci Ludwika Zieleniewskiego w 1885 roku zakład prowadzili jego synowie Leon i Edmund, a rozwijająca się fabryka produkowała również urządzenia tartaczne, młyńskie oraz maszyny parowe. Niestety w 1886 roku pożar strawił budynek kuźni i podjęto wówczas decyzję o przeniesieniu produkcji na Kleparz, do istniejącej od 1872 roku odlewni przy ul. Krowoderskiej 31 (Saryusz-Zaleski 1930: 159) (fot. 2). Nowe obiekty fabryczne wzniesiono tu wedle projektu Leona Zieleniewskiego, a kierownictwo fabryki przejął drugi z braci Edmund. Wybudowanie nowego zakładu było możliwe dzięki uzyskaniu dobrego odszkodowania. W 1905 roku w fabryce pracowało ponad 300 robotników, zajmowała ona obszar ponad 13 tys. $\mathrm{m}^{2}$ i dysponowała własną odlewnią. Znacznie poszerzono asortyment produktów, poza 110 typami urządzeń rolniczych, produkowano maszyny dla podkarpackiego zagłębia naftowego, szyny dla kolei galicyjskiej, stacje wodne dla kolei bałkańskich i halę dworca we Lwowie, a po 1881 roku także konstrukcje mostowe (Jasiuk 2007). W fabryce maszyn rolniczych prawdopodobnie odlano armaty dla powstańców 1863 roku. Poważnym ograniczeniem możliwości dalszego rozwoju był jednak brak bocznicy kolejowej. 


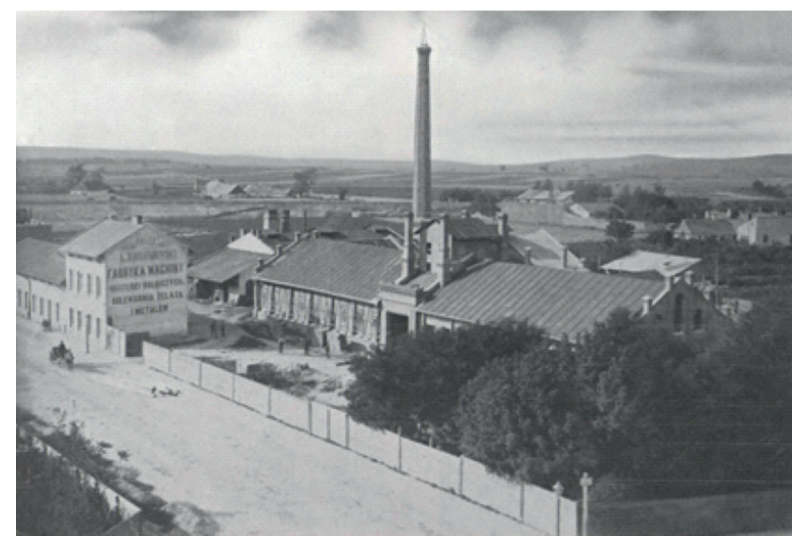

Fot. 2. Fabryka Zieleniewskich przy ul. Krowoderskiej 31 ok. 1890 r. Źródło: W. Saryusz-Zaleski (1930: 170)

Dla wzmocnienia ekonomicznego zakładów 21 maja 1906 roku w Wiedniu zawiązano Cesarsko-Królewską Uprzywilejowaną Fabrykę Maszyn L. Zieleniewski, Towarzystwo Akcyjne z udziałem banków austriackich, Zakładu Kredytowego dla Handlu i Przemysłu oraz Dolnoaustriackiego Towarzystwa Eskontowego, a także braci Ludwika i Edmunda Zieleniewskich. Kapitalizacja firmy wynosiła $1,5 \mathrm{mln}$ koron austriackich, w tym $1 \mathrm{mln}$ stanowił udział braci Zieleniewskich (fot. 3). Firma ta poprzez 15-letnią umowę kartelową była także powiązana z Towarzystwem Akcyjnym Budowy Maszyn Škoda, która wraz z austriackimi bankami dysponowała udziałami wysokości 33,3\%. Ponadto spółka zakupiła wkrótce Fabrykę Maszyn ks. Lubomirskiego we Lwowie i Pierwsze Galicyjskie Towarzystwo Akcyjne dla Budowy Maszyn i Wagonów w Sanoku (Wyka, Krzaczyńska 2001: 17-18; Zawistowski 2001: 10).
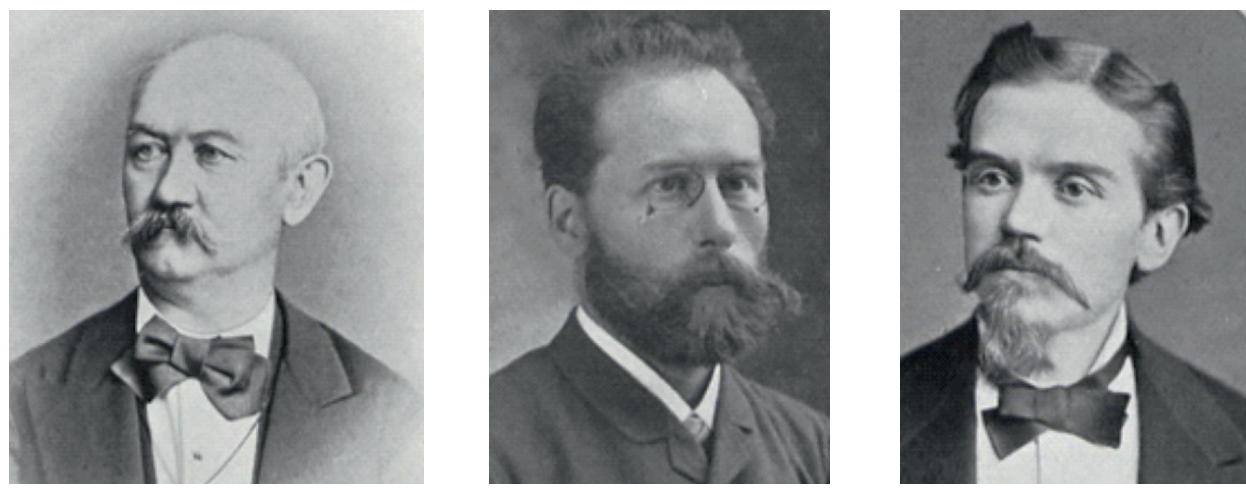

Fot. 3. Ludwik, Edmund i Leon Zieleniewscy

Źródło: W. Saryusz-Zaleski (1930: 115, 160) 


\section{Dzieje zagospodarowania wschodnich przedmieść Krakowa i rozwój funkcji przemysłowej}

Grzegórzki były podmiejską wsią odnotowaną po raz pierwszy w 1388 roku w dokumencie sprzedaży miastu wsi Grzegorszkowicze położonej za kościołem św. Mikołaja, nad nieistniejącą już odnogą Wisły, przez synów stolnika sandomierskiego Jana Borka - Jana i Piotra Borków (Nowak 2017: 5). Wcześniej tereny te należały w XI wieku do klasztoru w Tyńcu, w drugiej połowie XIV wieku do szlacheckich rodów, kolejno: Toporczyków herbu Leliwa, Spycymirów i Borków i od imienia jednego z właścicieli wywodzi się nazwę wsi wymienianą w różnych dokumentach także jako Grzegorzowicze, Grzegorzewice, Wola Grzegorzowska lub po niemiecku Gregersdorf. Pod obecną nazwą pojawiły się Grzegórzki w zapisie z 1542 roku (Tomkowicz 1926: 202). Władze Krakowa nabyły także sąsiednią wieś Dąbie (Eichwald) i skonsolidowały obie osady w jedną całość gospodarczą, od XV wieku dzierżawioną lub sprzedawaną z prawem wykupu zamożnym obywatelom lub krakowskim rajcom (Bąkowski 1911: 44), w tym Janowi Wierzynkowi i Janowi Morsztynowi starszemu (Nowak 2017: 5).

W okresie potopu szwedzkiego od 26 września 1655 roku najeźdźcy wykorzystywali m.in. obszar Grzegórzek i Dąbia podczas oblężenia Krakowa, gdzie ufortyfikowany obóz założył gen. Arvid Wittenberg (Sikora 1908: 14) (ryc. 1). Szwedzi wybudowali tymczasowy most przez Starą Wisłę (dziś w jej śladzie biegną ulice Dietla i Daszyńskiego), długości ok. 40 m, łączący Grzegórzki z Krakowem, położony nieco poniżej dzisiejszego mostu kolejowego przy ul. Grzegórzeckiej (Sikora 1908: 24). Szwedzi dokonali również korekty biegu rzeki Prądnik (od XIX wieku na obszarze Krakowa nazywanej Białuchą), która pierwotnie płynąc od północy na obszarze dzisiejszej Wieczystej gwałtownie skręcała na zachód i płynęła na południe od dzisiejszej ul. Kopernika aż do murów miejskich i następnie skręcała wzdłuż nich na południe uchodząc do Starej Wisły w okolicy dzisiejszej ul. Blich. Na tej rzece znajdowały się m.in. dzierżawione przez Kraków młyny koło kościoła św. Mikołaja na Wesołej i na Piasku, już na Grzegórzkach (Tobiasz 1974: 114). Dzisiejsze ujście Prądnika do Wisły na Dąbiu jest przekopem wykonanym przez Szwedów, aby osłabić strategiczne znaczenie rzeki płynącej pod murami miasta.

Obszar Grzegórzek cechowały bardzo niekorzystne warunki przyrodnicze, większość obszaru była podmokła, stale zalewana przez powodzie, słabo nadająca się dla działalności rolniczej, toteż przeważnie nieużytkowana (Sobczyński 1976: 8). Nie sprzyjało to w oczywisty sposób rozwojowi osadnictwa. Znajdującą się tu niewielką wieś spalili Szwedzi w 1655 roku, aby oczyścić przedpole do oblężenia Krakowa (Dahlberg 1696; Sobczyński 1976: 23). 


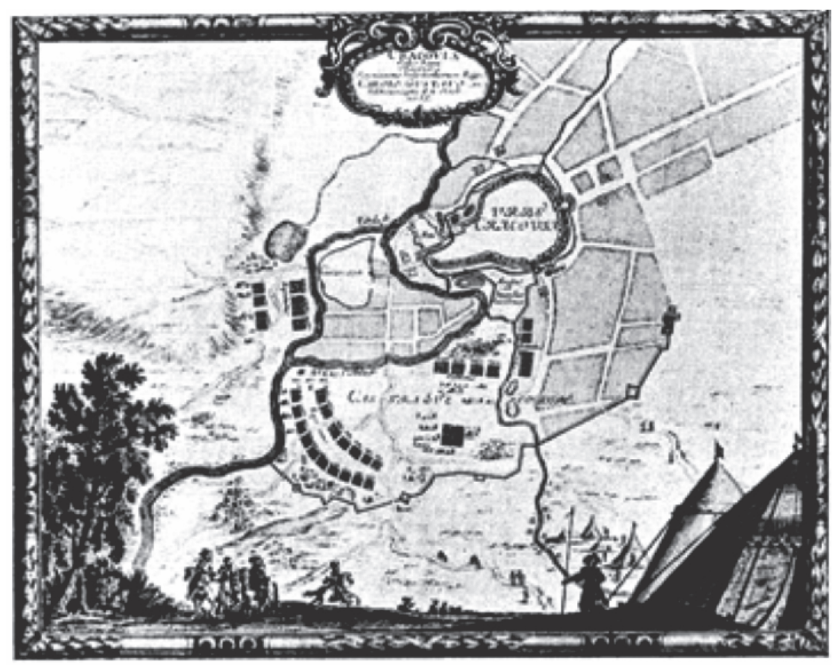

Ryc. 1. Plan Krakowa

z okresu oblężenia szwedzkiego w $1655 \mathrm{r}$.

Źródło: L. Sikora

(1908: 23)

Od XVIII wieku mieszkańcy Grzegórzek mieli obowiązek sprzątania miasta. Jak pokazuje Plan Miasta Krakowa, tzw. kołłątajowski z 1785 roku, cały obszar późniejszych zakładów Zieleniewskiego był terenem rolniczym (polami uprawnymi z niewielkim udziałem łąk, szczególnie nad Wisłą). Jedyną zabudowę stanowiło kilka budynków położonych na wschód od dzisiejszego Ronda Grzegórzeckiego, pomiędzy al. Pokoju i ul. Grzegórzecką, w miejscu gdzie dziś stoi Błękitek i budynki zakładów poligraficznych (ryc. 2).

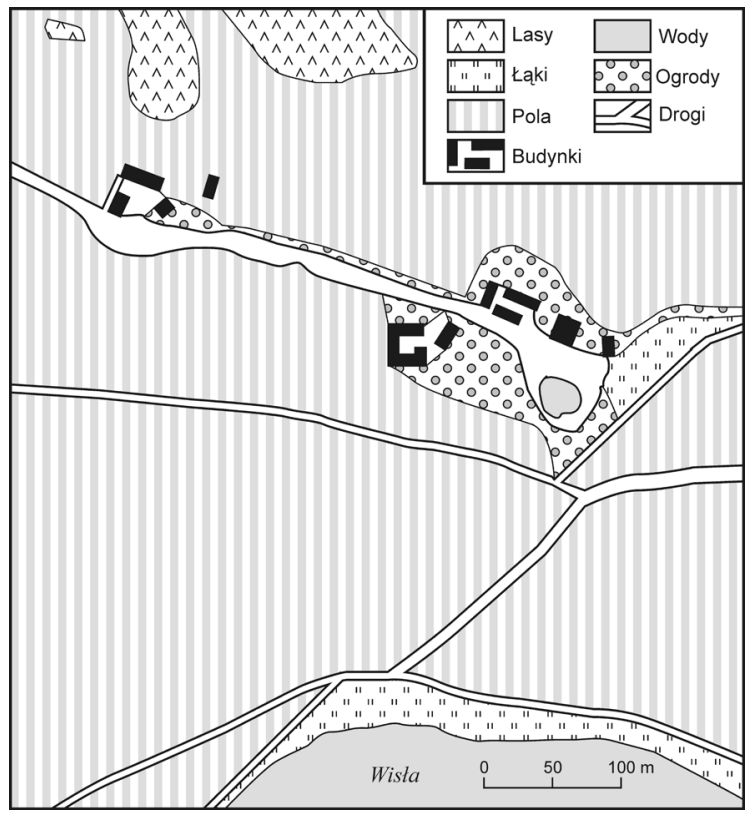

Ryc. 2. Badany obszar południowych Grzegórzek na mapie z $1785 \mathrm{r}$.

Źródło: J. Śniadecki,

F. Radwański (1785) 
Nieco inny od dzisiejszego był też układ dróg. Droga od starorzecza Wisły w miejscu późniejszej lokalizacji rzeźni miejskiej, w śladzie przecinającym dzisiejsze ulice Masarską i Gęsią, ciągnęła się dalej na wschód od dzisiejszej ul. Kotlarskiej (której wówczas nie było) i zaraz za nią rozdzielała się na dwie drogi, z których północna biegła równolegle do ul. Grzegórzeckiej w kierunku Dąbia, przez środek terenu późniejszych zakładów, przecinając obecną ul. Zieleniewskiego, zaś południowa była drogą nad brzegiem koryta Wisły, wówczas nieco szerszego w tym miejscu, biegła zatem dzisiejszym śladem wału wiślanego. Droga w śladzie ul. Grzegórzeckiej dochodziła jedynie do wspomnianych zabudowań i nie miała już kontynuacji ku Dąbiu. Od zachodu do zabudowań sięgała też droga w śladzie ul. Prochowej (Śniadecki, Radwański 1785). Na badanym obszarze znajdowały się prawdopodobnie jeszcze w XV wieku spore zagłębienia postawowe, po deszczu zapełniające się wodą (Bąkowski 1932: 36-37).

Z opisu miasta Krakowa Stanisława Kaweckiego z 1836 roku wynika, że wzdłuż obecnych al. Powstania Warszawskiego (dawnej ul. Okopy) i ul. Kotlarskiej, aż do Wisły (dziś Mostu Kotlarskiego) ciągnęły się militarne umocnienia ziemne (Kawecki 1927: 61). Za nimi miał się znajdować mostek na drodze ku Grzegórzkom, zamykany szlabanem, który pełnił rolę wschodniej rogatki miasta. Później przeniesiono ten szlaban na wschód od wsi Grzegórzki, na drogę do Dąbia (Kawecki 1927: 30, 61).

W połowie XIX wieku Grzegórzki wraz z położonymi na północ do nich Piaskami stały się gminą wiejską podległą magistratowi Krakowa. W 1838 roku Grzegórzki-Piaski zostały włączone do Krakowa, ale w 1852 roku władze austriackie anulowały tą decyzję (Nowak 2017: 6).

Pierwszą inwestycją zlokalizowaną na Grzegórzkach był austriacki Bastion VI wybudowany w 1866 roku nad Wisłą, który się zawalił. Na badany obszar wkraczał od zachodu i zajmował ok. 1/4 powierzchni współczesnego bloku urbanistycznego. Jego jedynym śladem jest fragment budynku prochowni, zachowany w postaci wapiennej ściany jednego z magazynów przy ul. Kotlarskiej 34 (fot. 4).

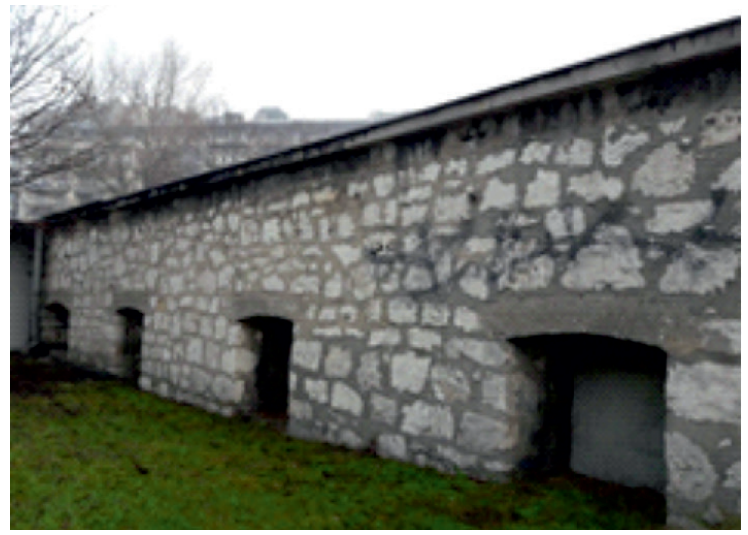

Fot. 4. Mur dawnej prochowni Bastionu VI, krakowskich fortyfikacji z 1866 r., ul. Kotlarska 34

Źródło: fot. M. Sobczyński 
Pionierskim zakładem produkcyjnym na Grzegórzkach była rzeźnia miejska (dziś obszar Galerii Kazimierz) przy ul. Rzeźniczej. Pierwsze jej obiekty powstały w 1818 roku (Kawecki 1927: 61). W 1871 roku według projektu Macieja Moraczewskiego wzniesiono budynki rzeźni, które przetrwały do 2004 roku, a jeden z nich został po rewitalizacji wkomponowany w Galerię Kazimierz (Chmiel 1932: 130; Encyklopedia Krakowa 2009: 268). Kolejno powstały na Grzegórzkach: Fabryka Wyrobów Stolarskich R. Muranyi'ego (ul. W. Pola 7), Parowa Fabryka Mebli, tartak S. Burzyńskiego oraz Fabryka Wyrobów Papierowych J. Pacanowskiego. Lokalizacji zakładów produkcyjnych poza miastem sprzyjał fakt znacznie niższych podatków, stąd dynamiczny rozwój przemysłu na Grzegórzkach, w Bieżanowie, Borku Fałęckim, Podgórzu i Płaszowie (Paciorek 1991: 12).

W 1869 roku Grzegórzki wraz z Piaskami zamieszkiwało 722 mieszkańców zajmujących 52 domostwa (Nowak 2017: 6). W 1890 roku wieś Grzegórzki-Piaski wraz z obszarem dworskim liczyła 2,1 tys. mieszkańców i 82 domy. W przededniu uprzemysłowienia tego obszaru w 1900 roku mieszkało tu już 3,4 tys. osób, stało 146 domów, funkcjonowała czteroklasowa szkoła ludowa (Encyklopedia Krakowa 2009: 268).

Zabudowa skupiała się wzdłuż ulic Grzegórzeckiej, Żółkiewskiego, Pasterskiej oraz $\mathrm{w}$ formie rozproszonej wzdłuż wschodniej pierzei ul. Piaski. Ulicę Kotlarską, którą wytyczono w latach 1880-1890 jako ważną strategicznie drogę poprowadzoną na zewnątrz fortyfikacji Twierdzy Kraków, zaczęto zabudowywać dopiero w okresie międzywojennym, przy czym w 1935 roku wzniesiono jedynie w jej wschodniej pierzei kamienicę narożną przy ul. Kotlarskiej 2 projektu Jana Zarzyckiego i sąsiednią przy ul. Kotlarskiej 4 z 1937 roku projektu Karola Bębna (fot. 5). Ci sami dwaj architekci zaprojektowali dalszą zabudowę tej pierzei nr 6 i 8 w 1934 roku, a Karol Bęben był projektantem kamienic pod nr 14 i 16 (fot. 6). Najpóźniej, bo w 1939 roku powstała kamienica przy Kotlarskiej 10 (Gminna ewidencja zabytków 2019). Obecną nazwę ulica ta, wcześniej określana jako Grzegórzecka-Boczna, otrzymała uchwałą Rady Miasta z dnia 2 grudnia 1937 r. (Nowak 2017: 56).

W 1899 roku przy dzisiejszej ul. Żółkiewskiego założono Cesarsko-Królewską Uprzywilejowaną Fabrykę Maszyn i Odlewarnię Marcina Peterseima produkującą maszyny rolnicze (budynek istnieje do dziś). Także w 1899 roku przez nadwiślańską część Grzegórzek przeprowadzono linię kolejową, tzw. Kocmyrzówkę (linia nr 111) długości $19 \mathrm{~km}$. Na badanym obszarze w dniu 14 grudnia $1899 \mathrm{roku}$ uruchomiono stację kolejową Kraków-Grzegórzki, wyposażoną w wieżę wodną (dziś jest tam podjazd z ul. Podgórskiej na Most Kotlarski). Z czasem od stacji poprowadzono bocznice kolejowe do lokalizowanych tu kolejno zakładów produkcyjnych. 

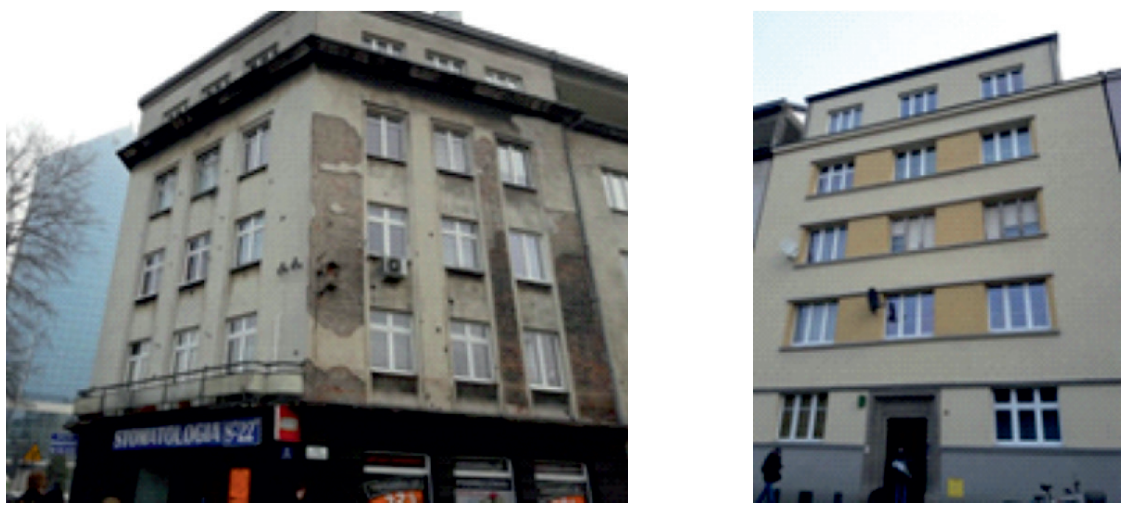

Fot. 5. Zabudowa czynszowa wschodniej pierzei ul. Kotlarskiej nr 2 i 4 z lat 30. XX w. Źródło: fot. M. Sobczyński
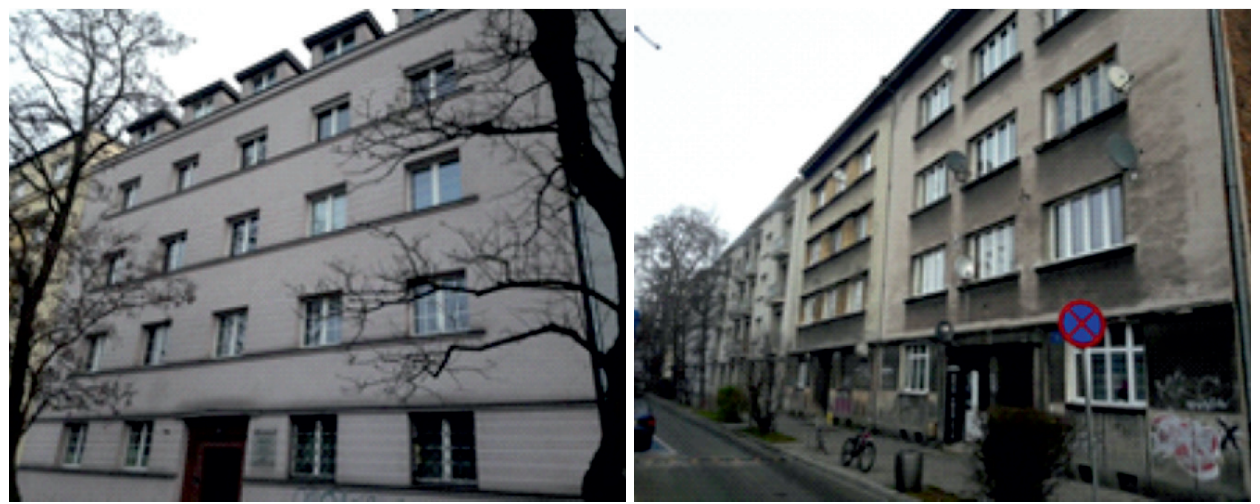

Fot. 6. Zabudowa czynszowa wschodniej pierzei ul. Kotlarskiej nr 6 oraz nr 14 i 16 z lat 30. XX w.

Źródło: fot. M. Sobczyński

Po przeniesieniu w 1906 roku na Grzegórzki Zakładów Zieleniewskiego, które stały się wkrótce największą fabryką w Krakowie, w dzielnicy tej ulokowano kolejne zakłady.

Około 1909 roku z ul. Dolnych Młynów przeniesiono na ul. Grzegórzecką 77 Fabrykę Gwoździ Braci Bauminger, zatrudniającą 150 robotników i produkującą na potrzeby wojska. Po drugiej wojnie światowej były to zakłady opakowań metalowych Artigraph (Opakomet).

W 1919 roku powstała Pierwsza Wytwórnia Autokaroserii i Powozów J. Orlickiego S.A. (samochody Durant), w 1926 roku polsko-szwajcarska Fabryka Czekolady „Suchard”, a w 1929 roku Polskie Zakłady Gumowe „Semperit”. 


\section{Rozwój zakładów Zieleniewskiego na badanym obszarze południowych Grzegórzek}

Konsolidacja kapitału braci Zieleniewskich w 1906 roku pozwoliła na znaczące zwiększenie skali produkcji. Nie było to jednak możliwe w centrum rozwijającego się Krakowa i zdecydowano zakupić w tym celu nowe tereny. Wybrano kilka sąsiadujących działek położonych na wschód od ówczesnych granic Krakowa, we wsi Grzegórzki (pomiędzy dzisiejszymi ulicami: Grzegórzecką, Zieleniewskiego, Kotlarską i brzegiem rzeki Wisły), które zakupiono w listopadzie 1906 roku. Plany nowych hal produkcyjnych przygotowało biuro projektowe Edmunda Zieleniewskiego. W chwili nabycia teren przy istniejącej już wówczas ulicy Grzegórzeckiej 69 miał charakter rolniczy. Łączna powierzchnia zakupionych za 87118 koron działek wynosiła $57857 \mathrm{~m}^{2}$.

Lokalizacja nad rzeką i obok linii kolejowej, od której doprowadzono do fabryki bocznicę, była optymalna. Nad Wisłą uruchomiono też stocznię rzeczną (Kalkowski 1961: 18). Koszty zakupu były bardzo niskie, za $1 \mathrm{~m}^{2}$ zapłacono 1,50 korony austriackiej, podczas gdy tereny przy ulicy Krowoderskiej wyceniono na 16,50 korony za $1 \mathrm{~m}^{2}$ (Saryusz-Zaleski 1930: 205). Oczywista była zatem nieopłacalność dalszego utrzymywania produkcji w centrum miasta i to bez perspektywy na jej zwiększenie w tym miejscu. W kolejnych latach, do 1912 roku, firma zakupiła sąsiednie działki na Grzegórzkach, łącznie uzyskując obszar o powierzchni $65830 \mathrm{~m}^{2}$, a wraz z otrzymanymi prawami do zabudowy cały obszar w posiadaniu Zieleniewskich miał powierzchnię $72430 \mathrm{~m}^{2}$. Był to teren znacznie większy niż potrzebny dla lokalizacji nowej fabryki, ale zarazem pozwalał na dalszą jej rozbudowę w przyszłości, kiedy po włączeniu Grzegórzek do Krakowa dnia 1 kwietnia 1910 roku ceny gruntów znacznie wzrosły.

Pierwszą inwestycję braci Zieleniewskich w nowej lokalizacji rozpoczęto wiosną 1907 roku wznosząc halę konstrukcji mostowych i centralę energetyczną. Produkcja w nowych obiektach ruszyła 15 marca 1908 roku. Jednak trudności ze zbyciem parceli przy ul. Krowoderskiej osłabiły nieco tempo dalszych inwestycji na Grzegórzkach (Saryusz-Zaleski 1930: 205). Inwestycję trzeba było sfinansować pożyczkami hipotecznymi oraz podniesieniem kapitału zakładowego w 1911 roku do 2 mln koron. W 1910 roku rozpoczęto budowę gmachu administracyjnego (zachował się do dziś) (fot. 7), a w 1911 roku rozpoczęto budowę hali maszyn i warsztatów mechanicznych, które uruchomiono wiosną $1912 \mathrm{roku}^{2}$ (ryc. 3). Nadal korzystano jednak ze starej odlewni przy ul. Krowoderskiej, a podobny obiekt na Grzegórzkach zaczęto budować w 1913 roku, lecz wojna przerwała tę inwestycję. W 1909 roku fabryka otrzymała zamówienie wykonania konstrukcji III mostu na Wiśle w Krakowie o wadze ponad $1 \mathrm{mln} \mathrm{kg.}$

\footnotetext{
${ }^{2}$ Autor składa podziękowanie Pani mgr Monice Cepil za przeprowadzenie kwerendy w Archiwum Narodowym w Krakowie.
} 

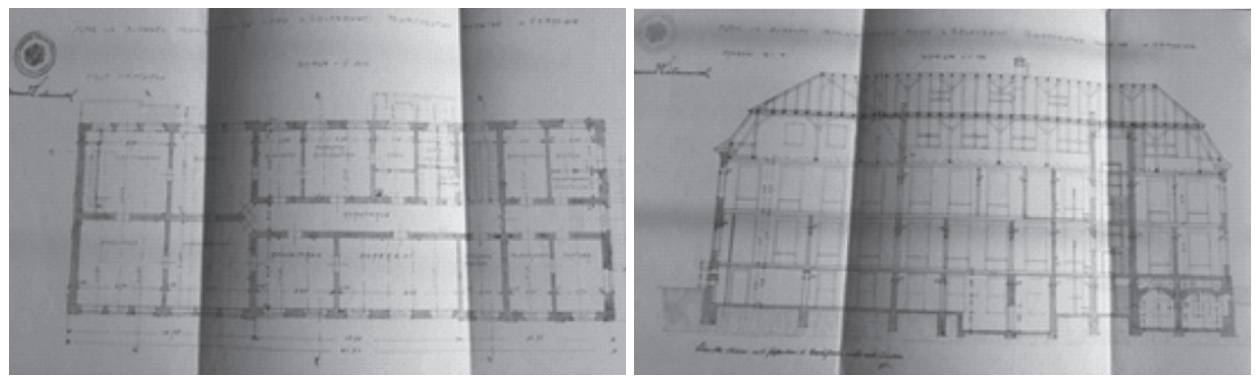

Fot. 7. Oryginały planu i szkicu architektonicznego gmachu dyrekcji z akceptującym podpisem Edmunda Zieleniewskiego z 1910 r.

Źródło: Archiwum Narodowe w Krakowie

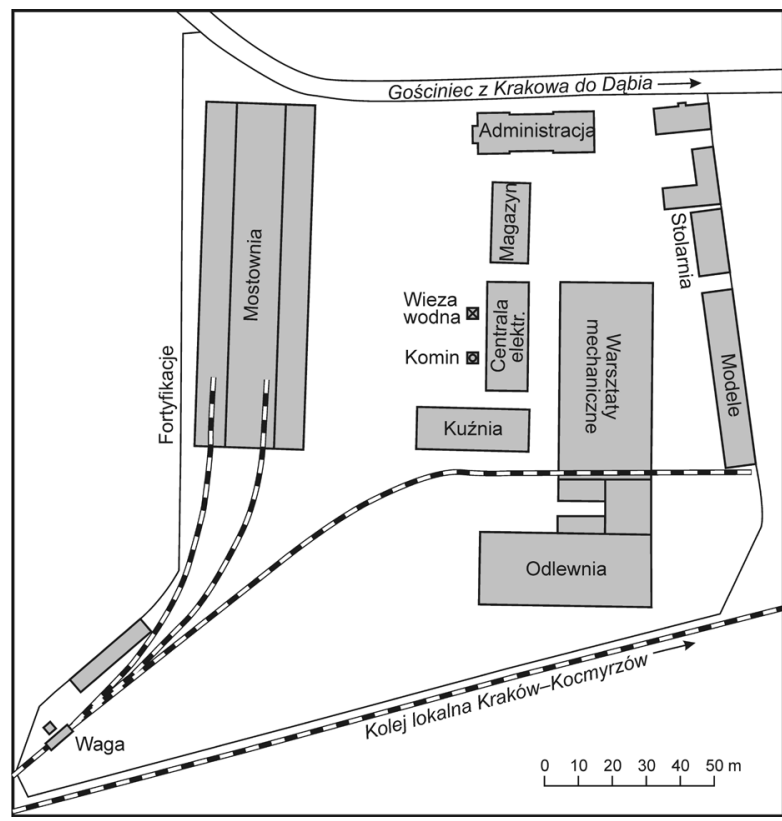

Ryc. 3. Plan Zakładów

Zieleniewskiego z $1911 \mathrm{r}$.

Źródło: Plan sytuacyjny

budynku... (1911)

Tuż przed wybuchem wojny w 1913 roku nastąpiła kolejna zamiana nazwy zakładów na Polskie Fabryki Maszyn i Wagonów L. Zieleniewski S.A. W okresie pierwszej wojny światowej krakowska część zakładów Zieleniewskiego (do kartelu należały też fabryki w Sanoku i Lwowie) znalazła się w stagnacji, już od jesieni 1914 roku w praktyce zaprzestała produkcji. Ogromny nabór pracowników do wojska (70\% załogi zmilitaryzowano) i bardzo nieliczne zamówienia wojskowe nie pozwalały na normalne funkcjonowanie, a w końcu listopada austriackie władze wojskowe formalnie zajęły zakład w celu przekształcenia go w warsztaty samochodowo-artyleryjskie, ale ostatecznie produkcji nie uruchomiono (Saryusz-Zaleski 1930: 231; Ważniejsze... 2001: 22) (fot. 8). 


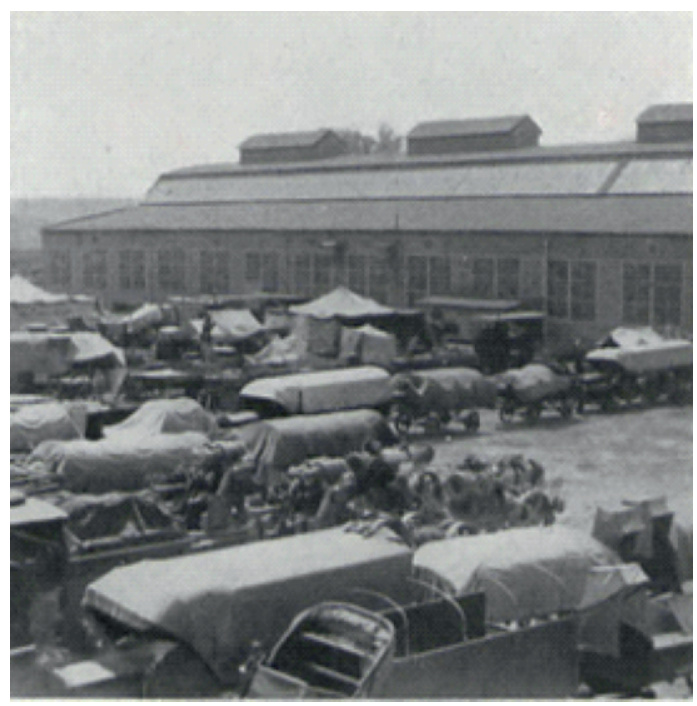

Fot. 8. Zakłady Zieleniewskiego w Krakowie zarekwirowane przez armię austro-węgierską w $1916 \mathrm{r}$.

Źródło: W. Saryusz-Zaleski

(1930: 237)

Dopiero w lipcu 1915 roku napłynęły pierwsze zamówienia i armia zwróciła mniej przydatne do produkcji maszyny. Wojsko opuściło fabrykę w marcu 1918 roku, do tego czasu jedynie montownia i kotlarnia były dostępne dla właścicieli zakładów i tylko tam prowadzono szczątkową produkcję. Inne zakłady przemysłowe Zachodniej Galicji nie były zajęte przez wojsko i okres wojny był dla nich czasem szczególnej prosperity. Paradoksalnie armia austro-węgierska nie zdołała wykorzystać potencjału zajętego zakładu, za to go silnie zdewastowała (Saryusz-Zaleski 1930: 232). W 1916 roku krakowskie zakłady zatrudniały tylko 60 pracowników, w 1918 roku udało się pozyskać kontyngent 20 jeńców rosyjskich.

Niestety, w marcu 1919 roku zmarł naczelny dyrektor spółki Edmund Zieleniewski i zastąpił go Antoni Lewalski (Saryusz-Zaleski 1930: 271). W początkach niepodległości Polski, fabryka zdobyła jednak sporo zamówień od przemysłu naftowego oraz od kolei i już w 1920 roku osiągnęła poziom produkcji najlepszych lat przedwojennych (fot. 9, 10). Dawni właściciele zakładów Zieleniewscy nie kontrolowali już jednak w pełni swojej fabryki, gdyż perturbacje finansowe sprawiły, że dominował kapitał bankowy: Banku Dyskontowego Warszawskiego, Banku Przemysłowego w Krakowie i Banku Gospodarstwa Krajowego (Ważiejsze daty... 2001: 22). W latach 1919-22 powiększono kapitał zakładowy spółki poprzez kilka kolejnych emisji obligacji, co pozwoliło na rozwój zakładów w niepodległej Polsce i zróżnicowanie asortymentu produktów. Spółka zakupiła kolejne grunty na Olszy w Krakowie z zamiarem lokalizacji fabryki wagonów, ale panująca inflacja zmusiła do korekty tego planu i ostatecznie zakupiono upadające zakłady w Ostrowie i tam rozpoczęto w 1920 roku budowę fabryki wagonów, którą po uruchomieniu wkrótce jednak sprzedano. 


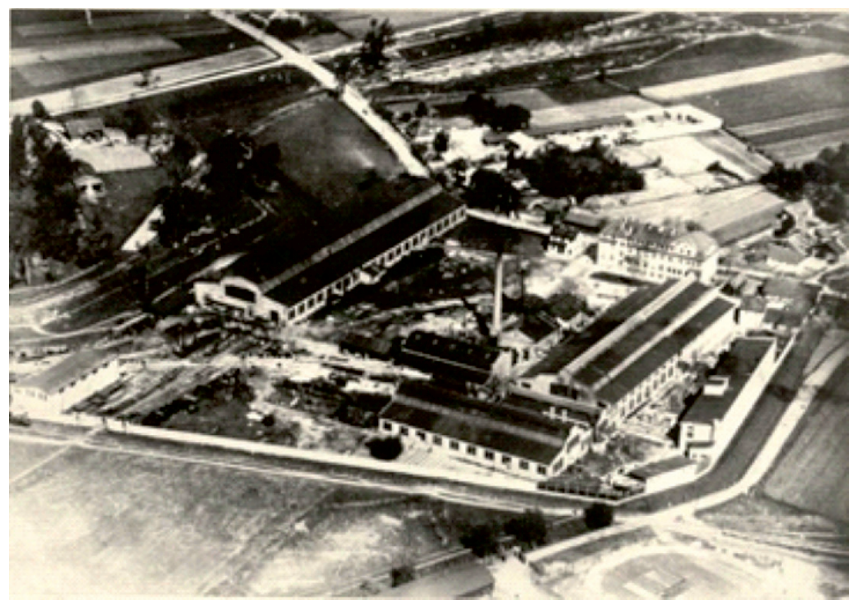

Fot. 9. Zakłady Zieleniewskiego ok. 1920 r.

Źródło: J.T. Nowak (2017: 43), zdjęcie lotnicze ze zbiorów Muzeum Historii Miasta

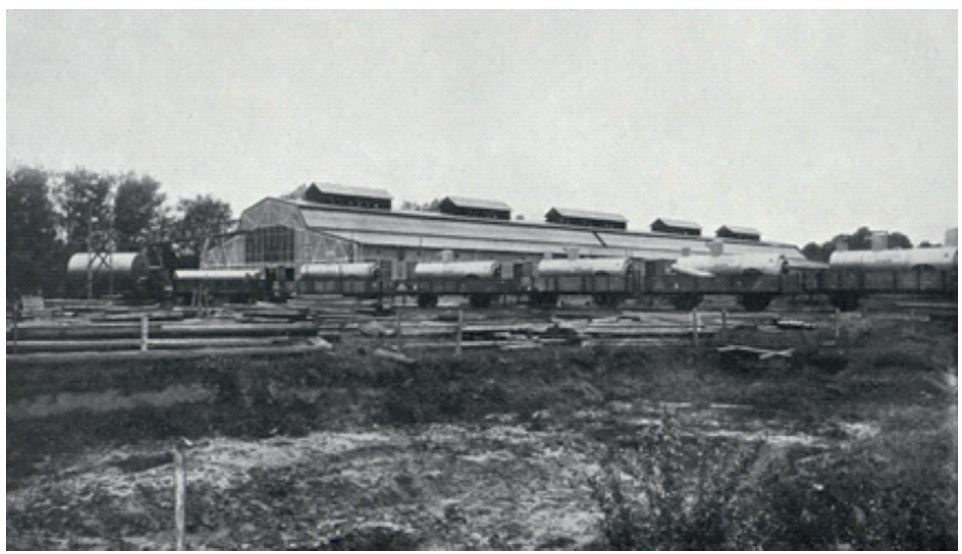

Fot. 10. Zakłady Zieleniewskiego, ul. Grzegórzecka 69, ok. 1920 r. Źródło: W. Saryusz-Zaleski (1930: 276)

Zakłady Zieleniewskiego związały się także w 1924 roku umową z brytyjską firmą Babcock and Wilcox z Londynu w sprawie produkcji kotłów w Krakowie. Jednym z odbiorców była Elektrownia Łódzka, która zamówiła dwa ogromne kotły o powierzchni grzewczej $1050 \mathrm{~m}^{2}$ i ciśnieniu 55 atmosfer. W krakowskich zakładach powstały też konstrukcje mostów kolejowego na Wiśle w Sandomierzu, mostu średnicowego w Warszawie i IV mostu w Krakowie. Od 1926 roku podjęto też produkcję statków rzecznych (tzw. monitorów dla marynarki wojennej), co oznaczało kolejną rozbudowę infrastruktury (ryc. 4, fot. 11). Tereny nabyte na Olszy, niewykorzystane produkcyjnie, zamieniono w tzw. kolonię pracowniczą 
zabudowaną domami dla 57 rodzin robotniczych o łącznej powierzchni $1682 \mathrm{~m}^{2}$ oraz obiektem klubu sportowo-kulturalnego Stowarzyszenia Kulturalno-Oświatowego „Zorza” o powierzchni $443 \mathrm{~m}^{2}$ (Saryusz-Zaleski 1930: 285).

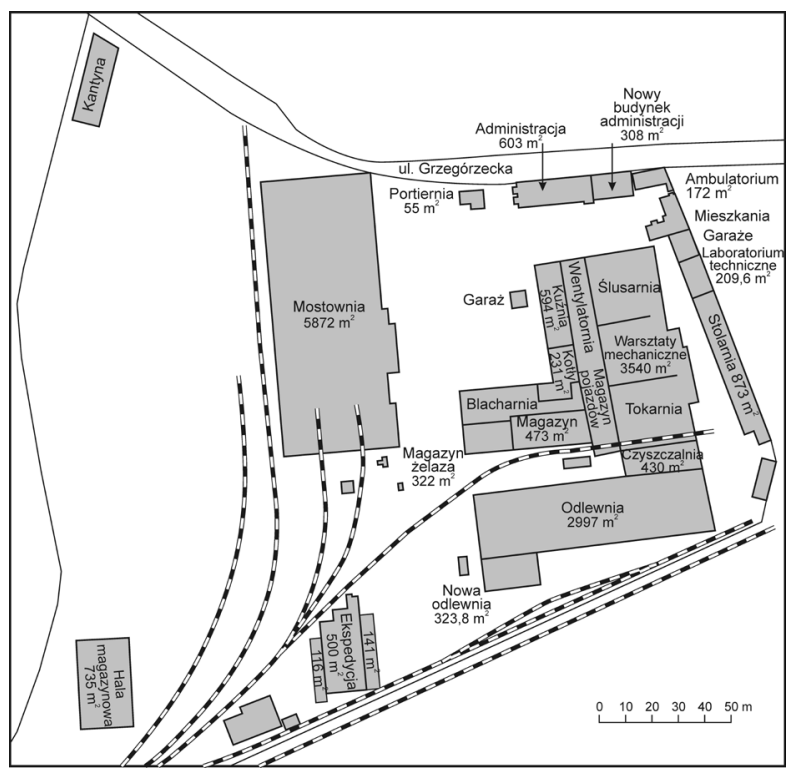

Ryc. 4. Plan Zakładów Zieleniewskiego z $1926 \mathrm{r}$. Źródło: Plan sytuacyjny fabryki... (1926)

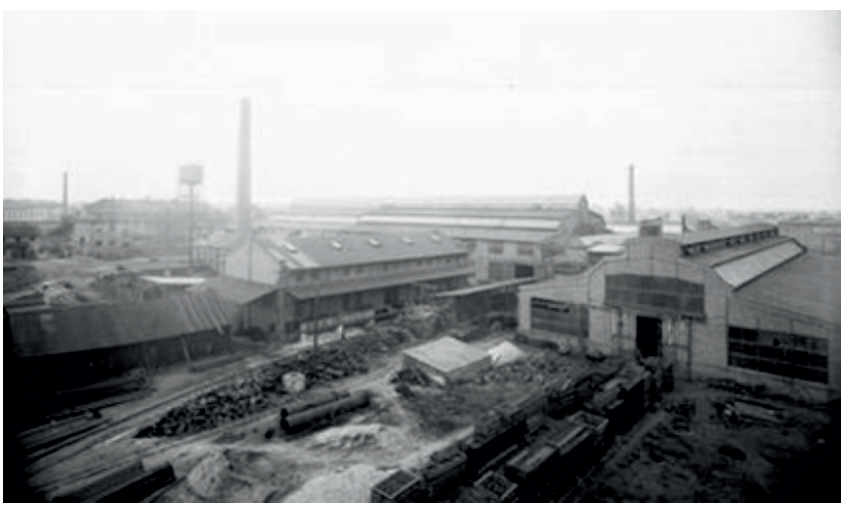

Fot. 11. Zakłady Zieleniewskiego w maju $1928 \mathrm{r}$.

Źródło: Narodowe Archiwum Cyfrowe, https://audiovis.nac.gov.pl/obraz/60786:1/ (dostęp: 1.11.2019)

Od 1 stycznia 1928 roku S.A.L. Zieleniewski połączyła się z S.A. Budowy Kotłów Parowych i Maszyn W. Fitzner, K. Gamper posiadającą zakłady w Sosnowcu i Dąbrowie Górniczej i nowa firma przyjęła nazwę Zjednoczone Fabryki Maszyn i Wagonów L. Zieleniewski i Fitzner-Gamper S.A. (fot. 12). W grudniu 1930 roku założono z firmą brytyjską nowe przedsiębiorstwo: Polskie Zakłady 
Babcock-Zieleniewski, którego dyrektorem był Edmund Zieleniewski jr. Spółka miała więc 7 zakładów (w Krakowie, Sanoku, Lwowie, Sosnowcu, Dąbrowie Górniczej, Tarnowskich Górach i Siemianowicach), a dyrekcję generalną w Krakowie przy ul. Grzegórzeckiej 69 (Ważniejsze daty... 2001: 25).

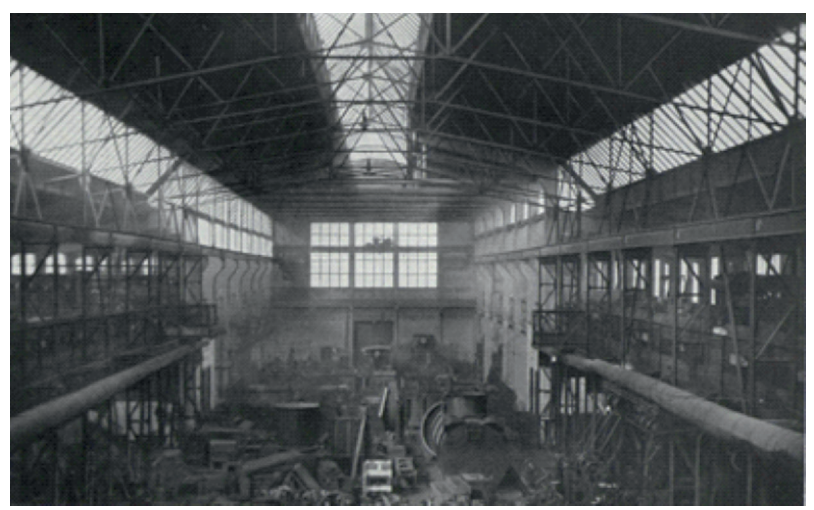

Fot. 12. Hala budowy maszyn w Zakładach Zieleniewskiego, ul. Grzegórzecka 69 w Krakowie

Źródło: W. Saryusz-Zaleski (1930: 289)

W zakładach na krakowskich Grzegórzkach produkowano kompletne urządzenia do rzeźni, chłodni, fabryk chemicznych, hutnictwa, górnictwa, stacje wodne, maszyny parowe, silniki diesla, kompresory, pompy, walce, pogłębiarki, statki, pontony, wentylatory, mosty, ruszty, suwnice, urządzenia transportowe, żurawie, wieże antenowe, urządzenia wiertnicze do wydobycia ropy i gazu. W filii sanockiej wytwarzano głównie pojazdy szynowe, wagony kolejowe, tramwajowe, karoserie oraz chłodnie. Zakłady we Lwowie produkowały młyny, odlewy i okucia, a w Sosnowcu kotły parowe i ruszty. Zakłady w Dąbrowie Górniczej wytwarzały obrabiarki, tokarki i frezarki, a w Siemianowicach zbiorniki na wodę, cysterny, beczki oraz rury stalowe, natomiast w Tarnowskich Górach rurociągi (Ważniejsze daty... 2001: 26).

Podczas słynnych rozruchów robotniczych w Krakowie z marca-września 1936 r., które ogarnęły wszystkie grzegórzeckie fabryki, Zakłady Zieleniewskiego stały się centrum dowodzenia strajkami. Już pierwszy z nich, tzw. strajk ekonomiczny przeprowadzony w dniach 21-23 marca, który objął także zakłady Semperit i Suchard zorganizował robotnik wyrzucony z pracy w Zakładach Zieleniewskiego Stanisław Szadkowski ps. „Karol”, członek Komunistycznej Partii Polski.

${ }^{3}$ Stanisław Szadkowski urodził się 25 marca 1895 r. we wsi Ostrowy k. Krośniewic w rodzinie zubożałej szlachty. W 1912 r. pracując jako tokarz w Sochaczewie związał się z SDKPiL. W 1918 r. przeniósł się do Łodzi, gdzie przystąpił do KPP. Podczas wojny polsko-sowieckiej 1920 r. aktywnie działał na rzecz propagandy komunistycznej 
W 1938 roku krakowska część fabryk Zieleniewskiego zatrudniała 1453 pracowników i była największym pracodawcą w krakowskim przemyśle. Trudności gospodarcze sprawiały, że moc produkcyjną tych zakładów wykorzystywano jedynie w 60\% (Paciorek 1991: 14) (fot. 13).

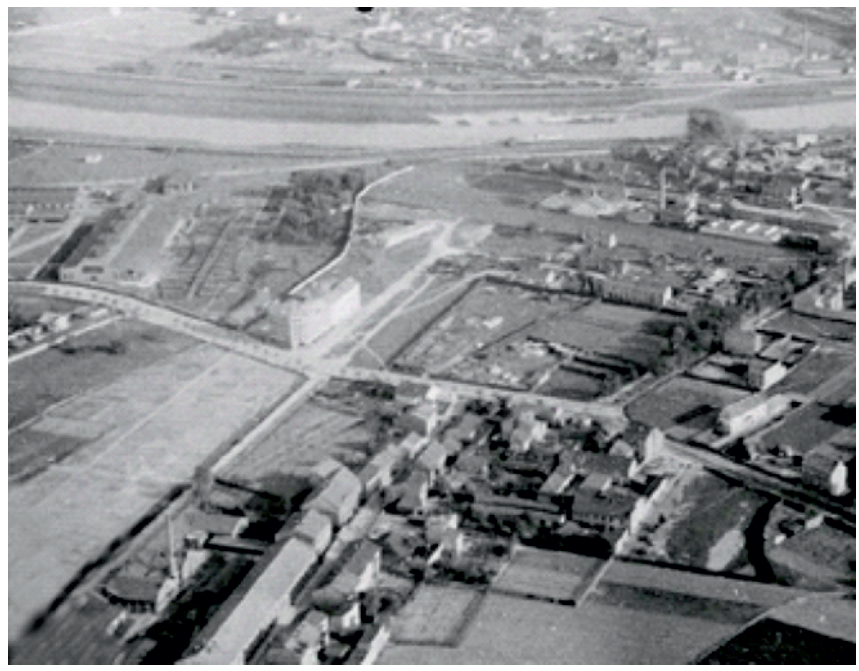

Fot. 13. Grzegórzki w 1936 r., w lewej górnej części zdjęcia widoczny fragment zabudowań Zakładów Zieleniewskiego Źródło: Muzeum Historyczne Miasta Krakowa, https://www.radiokrakow.pl/audycje/pod-lupa/pod-lupa-grzegorzki/ (dostęp: 1.11.2019)

W 1938 roku przy fabryce uruchomiono zakładowy Dom Socjalny przy ul. Grzegórzeckiej 71, przylegający od wschodu do budynku administracyjnego zakładów. Jest to duży modernistyczny budynek na rogu ulic Grzegórzeckiej i Zieleniewskiego, wyposażony w obszerną salę teatralno-kinową (fot. 14).

i dywersyjnej. W Krakowie schronił się przed policją ścigającą go za działalność antypolską. Zatrudnił się w zakładach wojskowych i nadal prowadził wrogą wobec Polski działalność. Po delegalizacji KPP został oddelegowany do Wydziału Wojskowego KC KPP w celu budowania wrogich struktur w Wojsku Polskim. Od 1925 r. pracował w Komitecie Dzielnicowym Grzegórzki-Dąbie KPP. W 1926 r. na polecenie KPP wstąpił do PPS-Lewicy, co wykorzystał do zakładania w Małopolsce i na Śląsku komunistycznych związków zawodowych. Za agenturalną działalność został w 1929 r. skazany na karę więzienia. W 1936 r. przez kilka tygodni pracował w zakładach Zieleniewskiego, ale zwolniono go, gdyż organizował tam komórkę KPP. Wzniecony przez Szadkowskiego strajk marcowy pochłonął życie 8 osób, w tym jednej kobiety, rannych było 20 robotników i 26 policjantów, a aresztowano 40 prowokatorów. Kolejny strajk okupacyjny w Zakładach Zieleniewskiego zorganizował w dniach 2-23 września 1936 r. (Figiel 1961: 28). Został aresztowany i jako element niebezpieczny osadzony w Berezie Kartuskiej. Po zwolnieniu nadal działał w krakowskim Komitecie Okręgowym KPP. Podczas okupacji S. Szadkowski założył tajną organizację pod nazwą „Polska Ludowa” związaną z Polską Partią Robotniczą. Podczas antykomunistycznej łapanki został aresztowany przez okupantów, osadzony w więzieniu przy ul. Montelupich, a następnie stracony 27 listopada 1942 r. w Niepołomicach. 

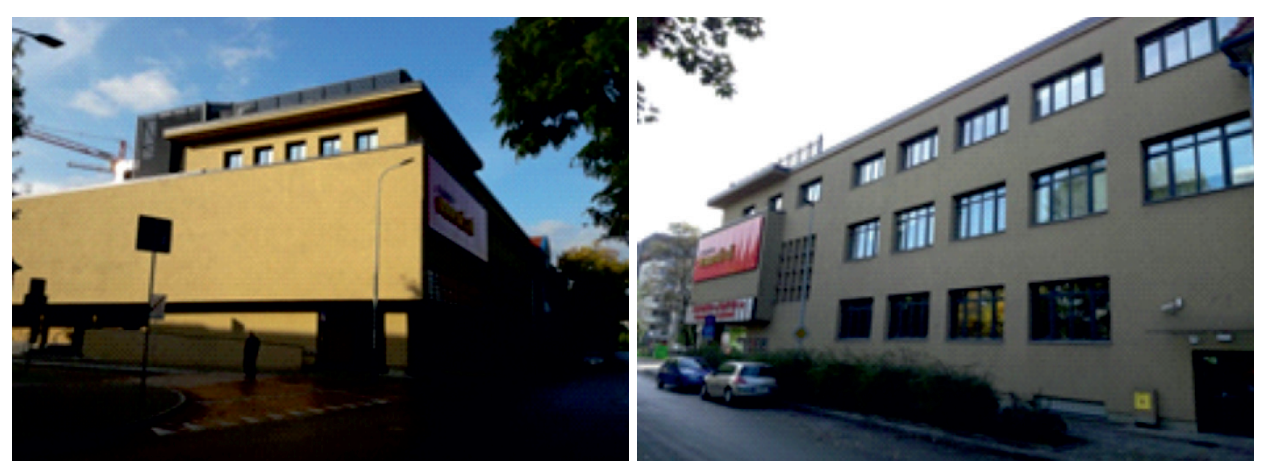

Fot. 14. Dom Socjalny Zakładów Zieleniewskiego, później Kino „Związkowiec”, obecnie Teatr „Variété”

Źródło: fot. M. Sobczyński

\section{Wojenne losy Zakładów Zieleniewskiego}

Wojska niemieckie wkroczyły do Krakowa 6 września 1939 roku. Okupanci przemianowali Zakłady Zieleniewskiego na Vereinigte Maschinen Kessel und Waggon Fabriken L. Zieleniewski und Fitzner Gamper Aktiongesselschaft, a pakiet kontrolny akcji 50,1\% należący do państwa, przekazano w 1941 roku koncernowi hr. Ballestrema rezydującego w Gliwicach (Paciorek 1991: 25). W 1940 roku zatrudnienie wynosiło tylko 800 osób, aby pod koniec wojny osiągnąć 1250 osób. W sierpniu 1944 roku do Niemiec wywieziono 80 robotników, relatywnie niewielu w stosunku do innych krakowskich fabryk. Robotnicy w tych zakładach byli też lepiej zaopatrywani w żywność i odzież (Paciorek 1991: 48). Produkcję dostosowano do potrzeb wojennych - wytwarzano miny i pociski, obudowy łodzi podwodnych i okrętów. Wykorzystali to pracownicy fabryki związani z Armią Krajową, którzy wynosili z niej materiały do produkcji broni (Stenów) wytwarzanej w warsztacie Domu Handlowego Sypniewski i Jakubowski przy ul. Mogilskiej 97. Niestety, Gestapo wykryło tę działalność i w konsekwencji 15 stycznia 1945 roku (na trzy dni przed wkroczeniem wojsk sowieckich) rozstrzelano na Dąbiu na wale wiślanym 79 osób, w tym również pracowników zakładu (Ważniejsze daty... 2001: 28-29) (fot. 15).

Od połowy 1944 roku rozpoczął się demontaż i wywóz do Niemiec maszyn z Zakładów Zieleniewskiego. Wywieziono aż 500 wagonów sprzętu. Zakład utracił aż 90\% parku maszynowego, w szczególności wszystkie nowoczesne obrabiarki. Pozostawiono jedynie stare maszyny mające niekiedy pół wieku. Drobne przedmioty próbowali ukryć w domach pracownicy zakładów. Sumę strat jakie poniósł w trakcie drugiej wojny światowej cały kartel Zieleniewskiego ocenia się na 17,1 mln zł, czyli 22\% majątku spółki (Paciorek 1991: 20, 51) (ryc. 5). 

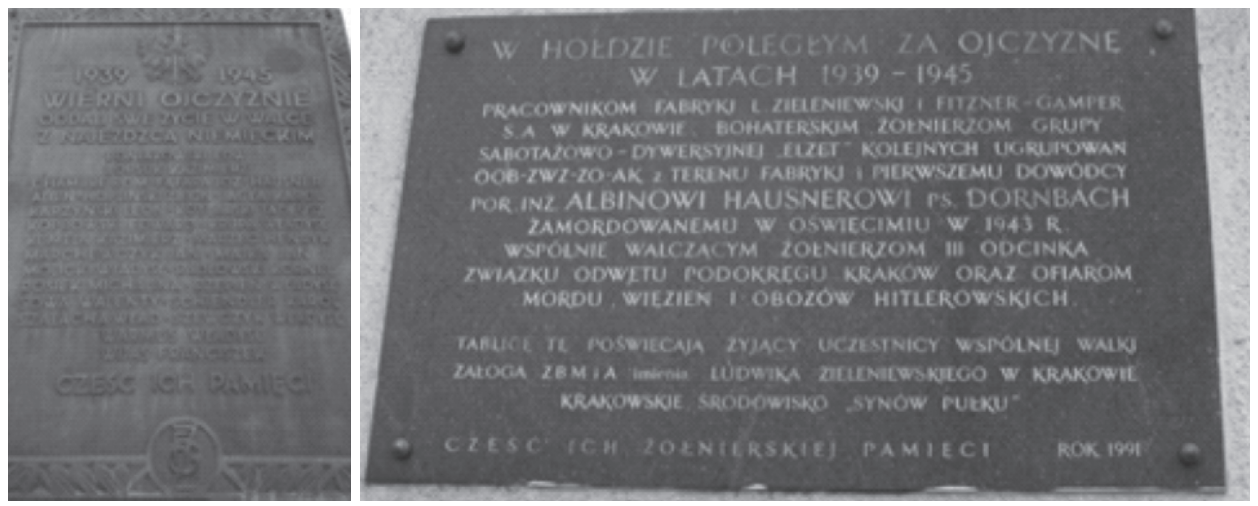

Fot. 15. Tablice na byłym budynku dyrekcji upamiętniające ofiary spośród załogi Zakładów Zieleniewskiego z okresu okupacji hitlerowskiej

Źródło: fot. M. Sobczyński

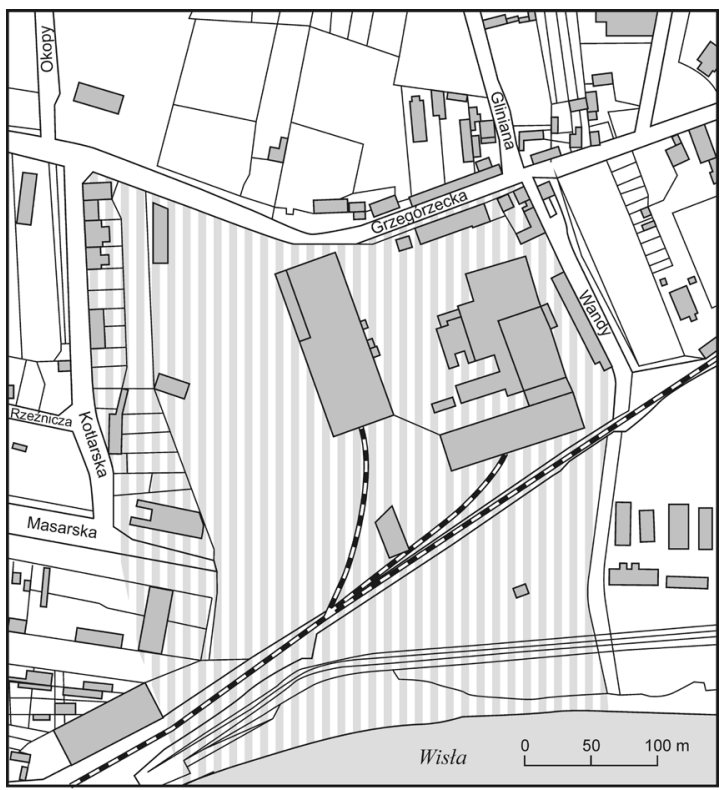

Ryc. 5. Badany obszar południowych Grzegórzek na mapie z 1944 r.

Źródło: Krakau (1944)

\section{Fabryka Zieleniewskiego w powojennej rzeczywistości ustroju socjalistycznego}

Już następnego dnia po zajęciu Krakowa przez wojska sowieckie, czyli 19 stycznia 1945 roku w Zakładach Zieleniewskiego pracownicy związani z PPR przejęli kontrolę nad produkcją. Delegacja zakładów spotkała się 20 stycznia z pełnomocnikiem Komitetu Ekonomicznego otrzymując zadanie odremontowania uszkodzo- 
nego III mostu na Wiśle (co wykonano już do 27 lutego) i uruchomienia uszkodzonej gazowni miejskiej (Stec 1961: 81-84). Na czele zarządu fabryki stał inż. Jerzy Weber, a przy ul. Grzegórzeckiej zatrudniano początkowo tylko ok. 100 pracowników, większość pracowała w innych krakowskich zakładach przygotowując ich rozruch oraz odbudowując pozostałe mosty na Wiśle (Paciorek 1991: 70).

Przez kilka kolejnych lat fabryka funkcjonowała pod przedwojenną nazwą Zjednoczone Fabryki Maszyn i Wagonów L. Zieleniewski i Fitzner-Gamper S.A. Maszyny pozyskiwano z rewindykacji w Gliwicach, Nysie i Wrocławiu. Już w styczniu 1945 roku uruchomiono dział mostowy, w połowie lutego ruszyła odlewnia, w marcu kuźnia, modelarnia i warsztaty mechaniczne. Pierwsza wypłata w gotówce nastąpiła w kwietniu 1945 roku, wcześniej zapłatą były przydziały żywności i odzieży. Jak wykazują sprawozdania, aż $20 \%$ załogi nie przychodziło do pracy, gdyż zatrudniali się w tym czasie u prywatnych przedsiębiorców płacących gotówką (Paciorek 1991: 72, 84). Bez wątpienia Zakłady Zieleniewskiego odegrały kluczową rolę w inicjalnym etapie odbudowy produkcji i transportu w Krakowie. W 1946 roku zatrudnienie w fabryce przekroczyło stan przedwojenny i wynosiło 1187 osób, ale produkcja liczona wagowo stanowiła tylko $36,3 \%$ przedwojennej, a wartościowo w przeliczeniu na jednego robotnika $46,6 \%$ (Paciorek 1991: 130). Poważnym problemem była fluktuacja kadr i to w obu grupach pracowniczych - robotników i nadzoru technicznego. W 1949 roku załoga liczyła już 1593 osoby, czyli 135\% przedwojennej i 167\% bezpośrednio powojennej. Wartość produkcji na jednego zatrudnionego nadal stanowiła tylko 74,8\% przedwojennej, ale już 1350\% tej z 1945 roku (Paciorek 1991: 133).

Zakłady Zieleniewskiego również w okresie powojennym doświadczyły akcji strajkowych, np. w grudniu 1947 roku i marcu 1948 roku żądano podwyżki zarobków o $120 \%$ i poprawy zaopatrzenia w odzież robotników i ich rodzin. W 1949 roku w Zakładach powstał Klub Techniki i Racjonalizacji (Paciorek 1991: 148).

Podobnie jak inne duże zakłady przemysłowe, fabryka Zieleniewskiego została znacjonalizowana przez polskie władze komunistyczne dekretem z dnia 3 stycznia 1946 roku. W przypadku omawianych zakładów faktyczne ich przejęcie przez państwo nastąpiło od 21 czerwca 1947 roku, a fabryka otrzymała nową nazwę Zakłady Mechaniczno-Kotlarskie nr 7 w Krakowie i podporządkowano je Zjednoczeniu Przemysłu Kotlarskiego (Stec 1961: 87; Nowak 2017: 44). Kolejny cios robotniczemu etosowi zakładów zadano w dniu święta 1 maja 1952 roku, kiedy aktyw partyjny na niesionym transparencie zaproponował nadanie fabryce imienia renegata i zaprzańca narodu polskiego Stanisława Szadkowskiego. Formalnie nastąpiło to 18 września 1952 roku (Stec 1961: 94-95). Patron w nazwie Zakładów Budowy Maszyn i Aparatury im. S. Szadkowskiego utrzymał się aż do 1990 roku.

Lata 50. XX wieku były trudne dla zakładów, gdyż budowa w pobliskiej Nowej Hucie kombinatu stalowego absorbowała dużą część robotników z fabryk na 
Grzegórzkach. Dopiero na początku lat 60. sytuacja kadrowa się ustabilizowała, a zakłady, nadal jedne z największych w Krakowie, podjęły działania o charakterze socjalnym. W latach 1948-52 rozbudowano i zmodernizowano według projektu arch. Zbigniewa Solawy Dom Socjalny, w którym organizowano zebrania załogi, wiece i akademie. Wieczorami sala o pojemności 800 osób pełniła rolę publicznego kina „Związkowiec” uruchomionego 22 lipca 1952 roku, jako pierwsze kino zakładowe. W okresie stalinowskich procesów Rejonowy Sąd Wojskowy wykorzystał tę salę do przeprowadzenia 21-23 stycznia 1953 roku publicznego procesu księży kurii krakowskiej. Zapadły wyroki trzykrotnej kary śmierci (których na szczęście nie wykonano) i wieloletnie wyroki więzienia (Stec 1961: 134; Nowak 2017: 48).

Zbudowano także Dom Matki i Dziecka, który w 1957 roku przekazano miastu uzyskując w zamian 35 izb mieszkalnych na Grzegórzkach oraz hotel robotniczy z 39 izbami. Wybudowano też dwa budynki mieszkalne przy ul. Marchewczyka, a w sierpniu 1961 roku trzeci dom. Otrzymano też dom kolonijny w Zawoi zdolny przyjąć 200 dzieci (Stec 1961: 138).

W otoczeniu zakładów w 1955 roku zmieniono układ komunikacyjny, kiedy wytyczono częściowo w śladzie ul. Okopy nową dwujezdniową aleję Powstańców Warszawskich (dziś al. Powstania Warszawskiego), pomyślaną jako fragment drugiej śródmiejskiej obwodnicy. Od 1959 roku rozpoczęto budowę dwujezdniowej al. Pokoju, od skrzyżowania ulic Grzegórzeckiej i Kotlarskiej poprowadzonej polami dawnych Piasków, przez nowe osiedla mieszkaniowe Grzegórzki i Dąbie do Ronda Czyżyńskiego i w zamyśle dalej do Nowej Huty, jako trzecia droga łącząca stary Kraków z nową dzielnicą mieszkaniowo-przemysłową. W 1969 roku al. Pokoju poprowadzono linię tramwajową wycofując ją ze wschodniego fragmentu zaślepionej z obu stron ul. Grzegórzeckiej.

W 1964 roku zakłady podporządkowano Zjednoczeniu Przemysłu Budowy Urządzeń Chemicznych „Chemak” w Warszawie. Na obszarze zakładów, w związku z rosnącą produkcją, sukcesywnie dobudowywano kolejne obiekty, lecz były to raczej konstrukcje lekkie, niejednokrotnie tylko w formie wiat i zadaszeń.

Przygotowany w 1977 roku miejscowy plan zagospodarowania przestrzennego krakowskiej dzielnicy Śródmieście, do której administracyjnie należał wówczas badany obszar południowych Grzegórzek, przewidywał zwiększenie udziału funkcji przemysłowej, kosztem redukcji, głównie substandardowej starej zabudowy mieszkaniowej. Planowano całkowite wyburzenie domów i kamienic przy ul. Żółkiewskiego, gdzie pierwotnie zamierzano zlokalizować Komitet Wojewódzki PZPR, lecz ostatecznie plan ten porzucono i zabudowa tej ulicy przetrwała do dziś. Także całość zabudowy domami jednorodzinnymi bez kanalizacji ul. Gęsiej miała być usunięta w związku z planem powiększenia obszaru sąsiednich Krakowskich Zakładów Przemysłu Gumowego (dawnego Semperitu) (Sobczyński 1976: 105-106). 
Natomiast na obszarze badanego bloku urbanistycznego zawierającym Zakłady Zieleniewskiego i ich otoczenie planowano także powiększenie terenów produkcyjnych. Najważniejszą inwestycją infrastrukturalną miało być przekształcenie al. Powstania Warszawskiego i ul. Kotlarskiej we fragment obwodnicy śródmieścia Krakowa i budowa w jej ciągu mostu drogowo-tramwajowego łączącego Grzegórzki z Podgórzem (Zabłociem). W pierwszym etapie w 1975 roku przebito ul. Kotlarską przez obszary składowe aż do Wisły (Sobczyński 1976: 110). W całości inwestycja ta została ostatecznie zrealizowana dopiero 8 grudnia 2001 r. (Nowak 2017: 56).

Na terenie Zakładów Budowy Maszyn, obejmującym obszar 10,8 ha oraz sąsiednich terenach magazynowych na obszarze 2,6 ha, planowano utrzymanie dotychczasowej funkcji przemysłowej i składowej. Poprawę zagospodarowania upatrywano jedynie $\mathrm{w}$, uporządkowaniu istniejącego zainwestowania na drodze uzupełnień i wymiany substancji”. Natomiast północny brzeg Wisły, wówczas nieurządzony, planowano przekształcić we fragment ogólnomiejskiego systemu zieleni, jako park z szerokim na $35 \mathrm{~m}$ bulwarem (wówczas ścieżka szutrowa miała $6 \mathrm{~m}$ szerokości). Miał tu obowiązywać zakaz lokalizacji obiektów kubaturowych, nawet tych prowizorycznych. Sama Wisła miała być poddana dalszej regulacji, obwałowaniu w celu dostosowania jej do potrzeb drogi wodnej (Plan Ogólny... 1977, sekc. A1.14.1.PS; A1.14.16.W). Ostatecznie Bulwar Kurlandzki, którego mury oporowe powstały już w latach 1905-1909 został oddany do użytku jako park i miejsce rekreacji w 2009 roku.

Omawiany plan zagospodarowania otoczenia Zakładów Budowy Maszyn i Aparatury przy ul. Grzegórzeckiej, przewidywał największe zmiany w otoczeniu tej fabryki. Nowe lokalizacje otrzymały położone na zachód od zakładów Spółdzielnia „Pszczelarz” (ul. Grzegórzecka 67, powierzchnia $3620 \mathrm{~m}^{2}$ ) oraz Krakowskie Przedsiębiorstwo Transportu Handlowego nr 4 (ul. Kotlarska 34, powierzchnia $6560 \mathrm{~m}^{2}$ ), a także położone na wschód od ówczesnej ul. Wandy (dziś ul. Zieleniewskiego) Zakłady Opakowań Blaszanych „Artigraph” (ul. Grzegórzecka 77, powierzchnia $13550 \mathrm{~m}^{2}$ ). Beneficjentem tych zmian miała być była fabryka Zieleniewskich, do której zamierzano przyłączyć tereny likwidowanych przedsiębiorstw. Jedynym warunkiem była zabudowa zwalnianej pierzei ul. Kotlarskiej budynkiem administracyjno-usługowym o wysokich walorach architektonicznych. Ulica Wandy miała pozostać ogólnodostępna, ale planowano jej przesunięcie ok. $100 \mathrm{~m} \mathrm{ku}$ wschodowi. Przydzielone fabryce obszary położone wzdłuż bulwaru wiślanego miały ograniczenie zabudowy wysokiej i dopuszczano tam jedynie funkcję magazynową. Istniejące nad Wisłą na końcu ul. Wandy urządzenia stoczni rzecznej też miały ograniczoną możliwość rozbudowy. Fragment ul. Grzegórzeckiej, który po budowie ronda Kotlarskiego stał się ulicą ślepą w odcinku pomiędzy Zakładami Zieleniewskiego a budowanym wówczas kombinatem poligraficznym, miał się stać wewnętrznym parkingiem dla obu zakładów (Sobczyński 1976: 49, 109-110). 
W latach 70. XX wieku fabryka Zieleniewskiego zatrudniała ponad 2 tys. pracowników (Nowak 2017: 46). Zakłady były patronem Szkoły Podstawowej nr 8 na Olszy, skąd rekrutowały uczniów do szkoły zawodowej funkcjonującej przy fabryce. W 1978 roku powstało Muzeum Zakładowe (Zawistowski 1979). W okresie aktywności pierwszej „Solidarności” w 1981 roku z inicjatywy jednego z potomków Ludwika Zieleniewskiego - Wiktora, w zakładach przeprowadzono referendum w sprawie przywrócenia imienia pierwotnego ich patrona. Wprowadzenie stanu wojennego powstrzymało jednak ten proces na dekadę.

\section{Losy Zakładów Zieleniewskiego po transformacji ustrojowej w 1989 roku}

Po transformacji ustrojowej w 1990 roku grzegórzeckim Zakładom Budowy Maszyn i Aparatury przywrócono imię Ludwika Zieleniewskiego. Niestety, fabryka nie zdołała się już przystosować do reguł gospodarki rynkowej, a jej lokalizacja w miejscu, do którego przemieściło się centrum administracyjne Krakowa stawała się sprzeczna z ekonomiką produkcji przemysłowej. W drugiej połowie lat 90. XX wieku regres Zakładów Zieleniewskiego się pogłębił. Nie podjęto próby restytucji fabryki spadkobiercom byłych właścicieli, gdyż nie byli oni zdolni finansowo, aby przejąć zakład. Najcenniejszy element - odlewnię kupiła w 1996 roku stara krakowska firma Wolfram. Natomiast w 1998 roku pozostałe 4,8 ha powierzchni fabryki nabyła spółka Pergranso (zarządca w Polsce sieci handlowej E. Leclerc). Nie podjęła tu jednak żadnych działań inwestycyjnych. Jeszcze w 2004 roku odbyły się uroczystości 200-lecia istnienia zakładów Zieleniewskiego (Nowak 2017: 46) (fot. 16). Nadal działało kino „Związkowiec”, które dla uatrakcyjnienia oferty przyjęło profil studyjny.

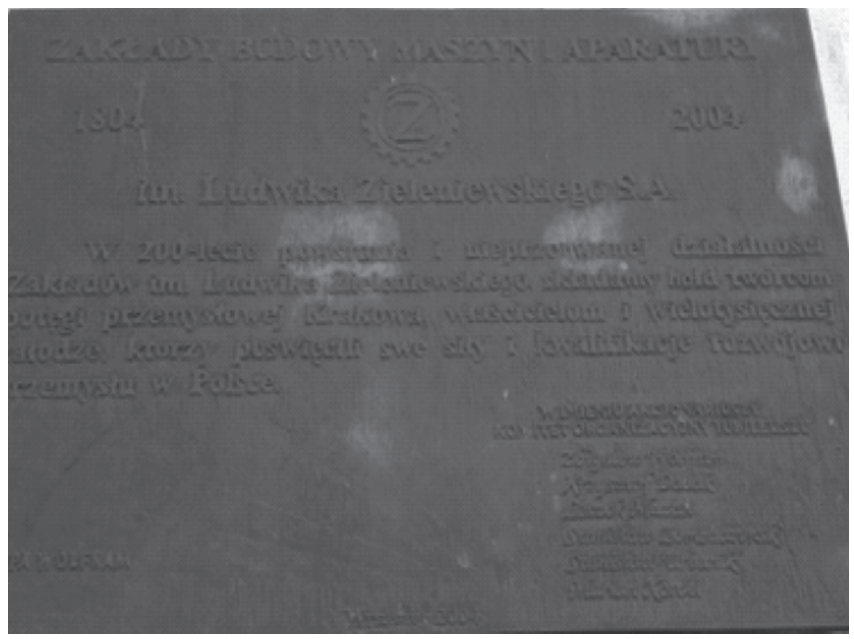

Fot. 16. Tablica na byłym gmachu dyrekcji

Zakładów upamiętniająca obchody ich 200-lecia w $2004 \mathrm{r}$.

Źródło: fot. M. Sobczyński 
Dokładnie w stulecie przenosin fabryki z ul. Krowoderskiej poza miasto, na Grzegórzki, prezes spółki Agata Czauderna ogłosiła 11 grudnia 2006 roku, że ZBMiA im. L. Zieleniewskiego zakupiły działkę w Niepołomicach, ponownie decydując się na przenosiny poza Kraków. Koszty remontu starych hal byłyby zbyt wysokie, a dotychczasowa lokalizacja, niegdyś peryferyczna, oznacza współcześnie sąsiedztwo z głównymi urzędami administracji miasta i województwa, co nie może być obojętne dla kosztów utrzymania tych gruntów. W latach 2008-2009 firma Wolfram zlikwidowała wszelką produkcję na badanym terenie i przeniosła ją do byłej garbarni w Niepołomicach, przy ul. Garbarskiej 11.

Po przeniesieniu produkcji do Niepołomic obiekty byłych Zakładów Zieleniewskiego pozostały niezagospodarowane i popadały w ruinę. Zamknięto także kino „Związkowiec” i przez kilka lat obiekt stał pusty.

Uchwałą Rady Miasta z 21 marca 2012 roku uliczkę Wandy przemianowano na ul. Ludwika Zieleniewskiego, a prywatni deweloperzy szybko zabudowali jej wschodnią pierzeję na terenach dawnych zakładów Artigraph, lokując tam kilka budynków mieszkalno-usługowych (Nowak 2017: 50). W 2019 roku dotąd ślepą ul. Zieleniewskiego połączono z poprowadzoną od Węzła Kotlarskiego, w śladzie byłego toru kolejowego, nową ulicą prof. Marka Stachowskiego.

Doceniono też walory architektoniczne gmachu byłego kina „Związkowiec” i z dniem 21 stycznia 2014 roku wpisano go na listę zabytków. Akt ten dał asumpt do gruntownego remontu po 6 latach od zakończenia działalności przez kino, byłego Domu Socjalnego Zakładów Zieleniewskiego, w którym 31 maja 2015 roku zainaugurował działalność Krakowski Teatr „Variété” pod kierownictwem Janusza Szydłowskiego i Agnieszki Miki (Nowak 2017: 49) (fot. 14). Przejęcie i dostosowanie budynku do potrzeb teatru kosztowało władze miasta $27,5 \mathrm{mln}$ zł.

W 2009 roku na obszarze odkupionym od Pergranso rozpoczęto budowę zamkniętego osiedla apartamentowców pod nazwą „Wiślane Tarasy”. Nabywcą działki położonej pomiędzy zabudową czynszową ul. Kotlarskiej a istniejącymi jeszcze wówczas halami Zakładów Zieleniewskiego była jedna z największych krakowskich spółek deweloperskich - Grupa Inter-Bud, założona w 1989 roku. Pierwszy etap budowy realizacji osiedla złożonego z 6 bloków zakończono w 2017 roku, kiedy oddano do użytku ostatni 5-piętrowy budynek nr 4. Jest to jeden z dwóch łukowatych bloków położonych najbliżej Wisły. Pozostałe cztery bloki położone amfiteatralnie o tarasowej architekturze maja kształt litery C, przy czym fragmenty poprzeczne $\mathrm{w}$ dwóch $\mathrm{z}$ nich są równe, a w dwóch pozostałych (tych zachodnich) północne fragmenty są dłuższe niż południowe (fot. 17). Zróżnicowana jest powierzchnia oferowanych mieszkań od 30 do $142 \mathrm{~m}^{2}$. W innych blokach oferta jest podobna, powierzchnia mieszkań zaczyna się od $25 \mathrm{~m}^{2}$, ale są też bliskie $100 \mathrm{~m}^{2}$. Ich ceny zawierają się w kwotach od 250 tys. zł do powyżej 900 tys. zł (Wiślane Tarasy 2014). 

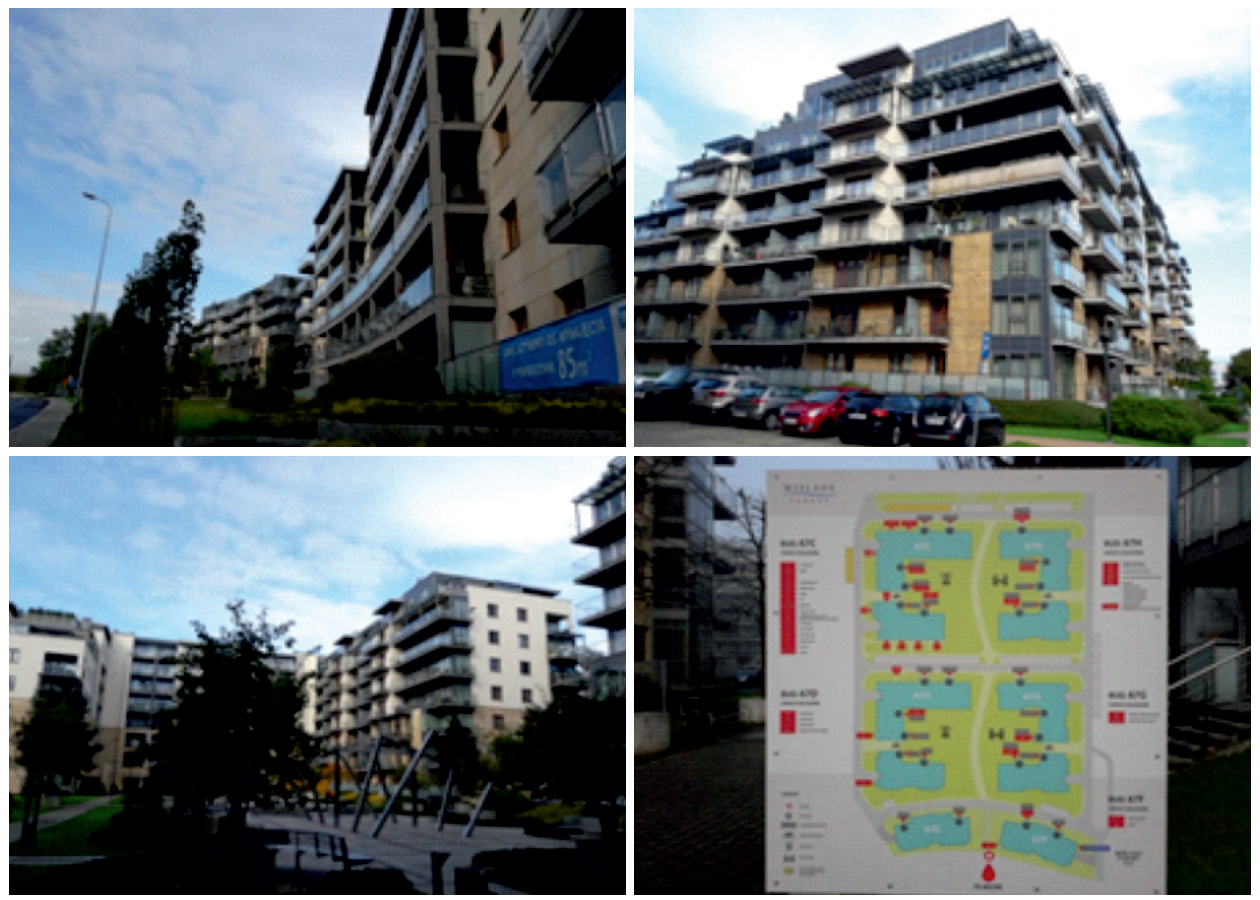

Fot. 17. Osiedle apartamentowców „Wiślane Tarasy” w zachodniej części byłych Zakładów Zieleniewskiego (pierwsza część inwestycji z lat 2017-18)

Źródło: fot. M. Sobczyński

Pod budynkami znajdują się wielostanowiskowe garaże połączone cichobieżną windą z piętrami mieszkalnymi. Przestrzeń wokół bloków jest starannie zagospodarowana i tworzy spójną całość. Zaaranżowano ją jako zieleń międzyblokową wyposażoną w place zabaw dla dzieci, miejsca do rekreacji dla dorosłych, wypoczynku oraz obiekty małej architektury podnoszącej wartość wizualną przestrzeni. Całość inwestycji, począwszy od lokalizacji nad Wisłą z tarasowym rozplanowaniem budynków, a zarazem w dopiero się kształtującym nowym CBD Krakowa i oddaleniem ok. $300 \mathrm{~m}$ od Galerii Kazimierz ma prestiżowy, luksusowy i snobistyczny wymiar, jak również adekwatne ceny mieszkań. W praktyce po dwóch latach od oddania ostatnich bloków nie ma tu już wolnych lokali. W parterach budynków ulokowano placówki usługowe, z widoczną nadreprezentacją prywatnych placówek ochrony zdrowia oraz sklepem spożywczym, fryzjerem i gabinetem kosmetycznym. W osiedlu jest też prywatny żłobek. Pierwszy etap budowy „Wiślanych Tarasów” uzyskał nagrody w kilku konkursach architektonicznych i urbanistycznych.

Drugi etap budowy osiedla „Wiślane Tarasy” 2.0, realizowany przez tego samego dewelopera, obejmuje obszar po zburzonych halach Zakładów Zieleniew- 
skiego, co jest zresztą wykorzystane do reklamowania inwestycji w prospekcie, jako miejsce z 200-letnią tradycją. Architektura jest jeszcze nowocześniejsza niż w pierwszym etapie, a kształty budynków zdecydowanie obłe, w jednym przypadku jest to obiekt wręcz owalny. Otoczenie będzie aranżowane podobnie jak w już istniejącej części (na razie obie części oddziela prowizoryczne ogrodzenie), a twórcy jednoznacznie w swoich planach wzorują się na singapurskim „Podniebnym Lesie", preferując modernistyczne aluminiowe i drewniane formy małej architektury „stalowych drzew”. Zielone mają też być dachy bloków, a całe osiedle reklamowane jest jako ekologiczne.

W 2019 roku oddano już pierwszy z planowanych pięciu 10-piętrowych budynków - obiekt A, położony najbliżej Wisły. Kolejny budynek D będzie gotowy pod koniec roku 2020. Powierzchnia oferowanych lokali zawiera się między ok. $33 \mathrm{~m}^{2}$ a $230 \mathrm{~m}^{2}$, a ich ceny oscylują od ok. 390 tys. zł do powyżej 4,6 mln zł. Za mieszkanie powyżej $50 \mathrm{~m}^{2}$ trzeba zapłacić ponad 600 tys. zł. Inwestor nie podaje jeszcze daty rozpoczęcia budowy kolejnych bloków, zapewne czekając na efekt sprzedaży już zaoferowanych dwóch (Wiślane Tarasy 2.0, 2019) (fot. 18).
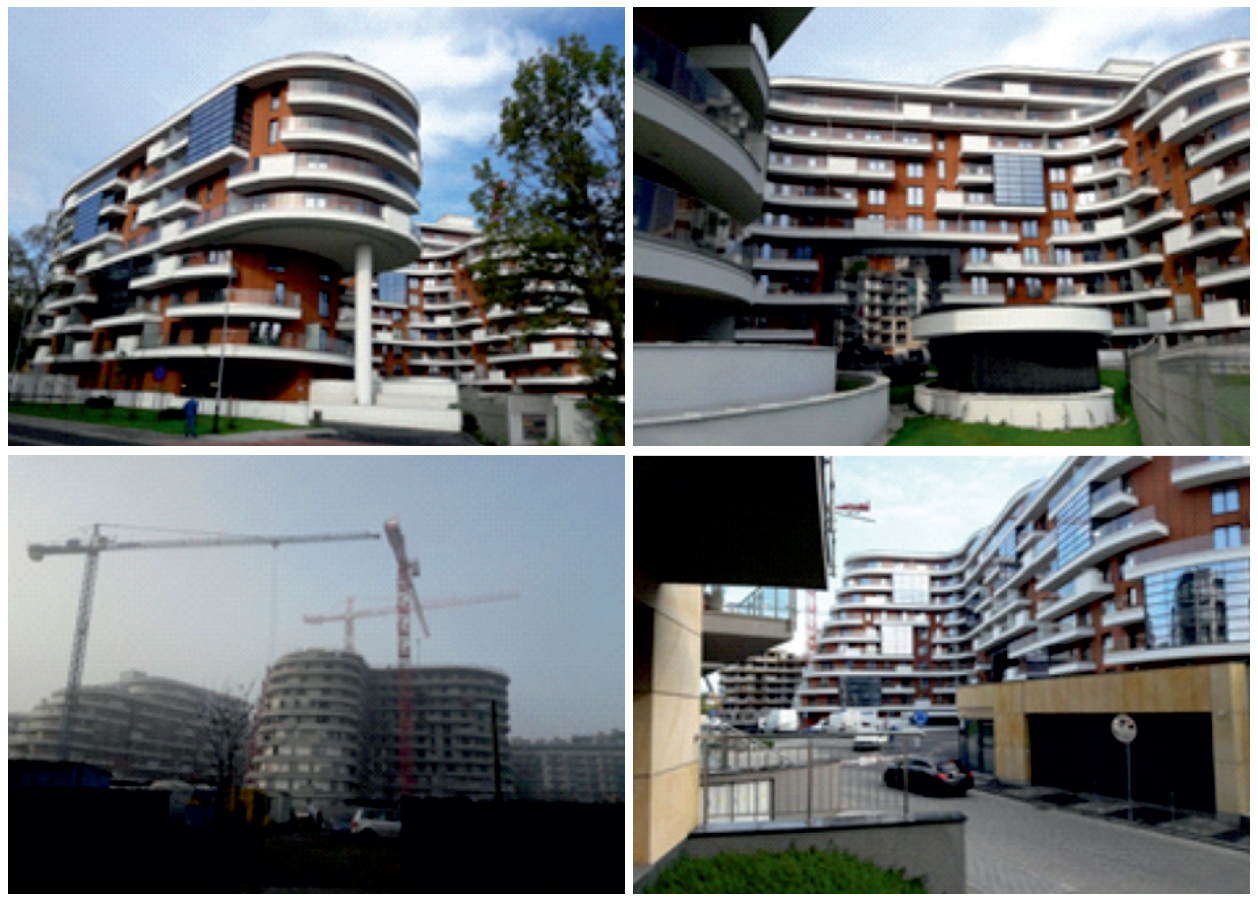

Fot. 18. Osiedle apartamentowców „Wiślane Tarasy” we wschodniej części byłych Zakładów Zieleniewskiego (druga część inwestycji z lat 2019-21)

Źródło: fot. M. Sobczyński 
Za dawną bocznicą kolejową już nad samą Wisłą, w byłej strefie magazynowej (obecnie przy ul. prof. M. Stachowskiego 4) w końcu 2018 roku oddano do użytku apartamentowiec „Pianissimo” o szczególnej urodzie, stający się jedną z wizytówek Grzegórzek (fot. 19). Inwestycja ta przesłoniła widok na rzekę mieszkańcom pierwszego etapu budowy „Wiślanych Tarasów”. Inwestorem jest polska firma z Warszawy Green House Development.

„Pianissimo” składa się ze 181 mieszkań o powierzchni $54-57 \mathrm{~m}^{2}$ rozmieszczonych na 7 piętrach, posiada podziemne miejsca parkowania (70) oraz 11 lokali użytkowych na parterze. Wszystkie mieszkania są już zasiedlone (Pianissimo 2019). Ceny mieszkań zaczynały się od ponad 600 tys. zł.

Władze miasta nie pozostały obojętne wobec zmian w tej części Krakowa i zrewitalizowały nabrzeże Wisły, w tej części uregulowanej, przeznaczając je na potrzeby czynnej rekreacji. Doprowadzono też nowe ulice do powstającego osiedla mieszkaniowego „Wiślane Tarasy”.
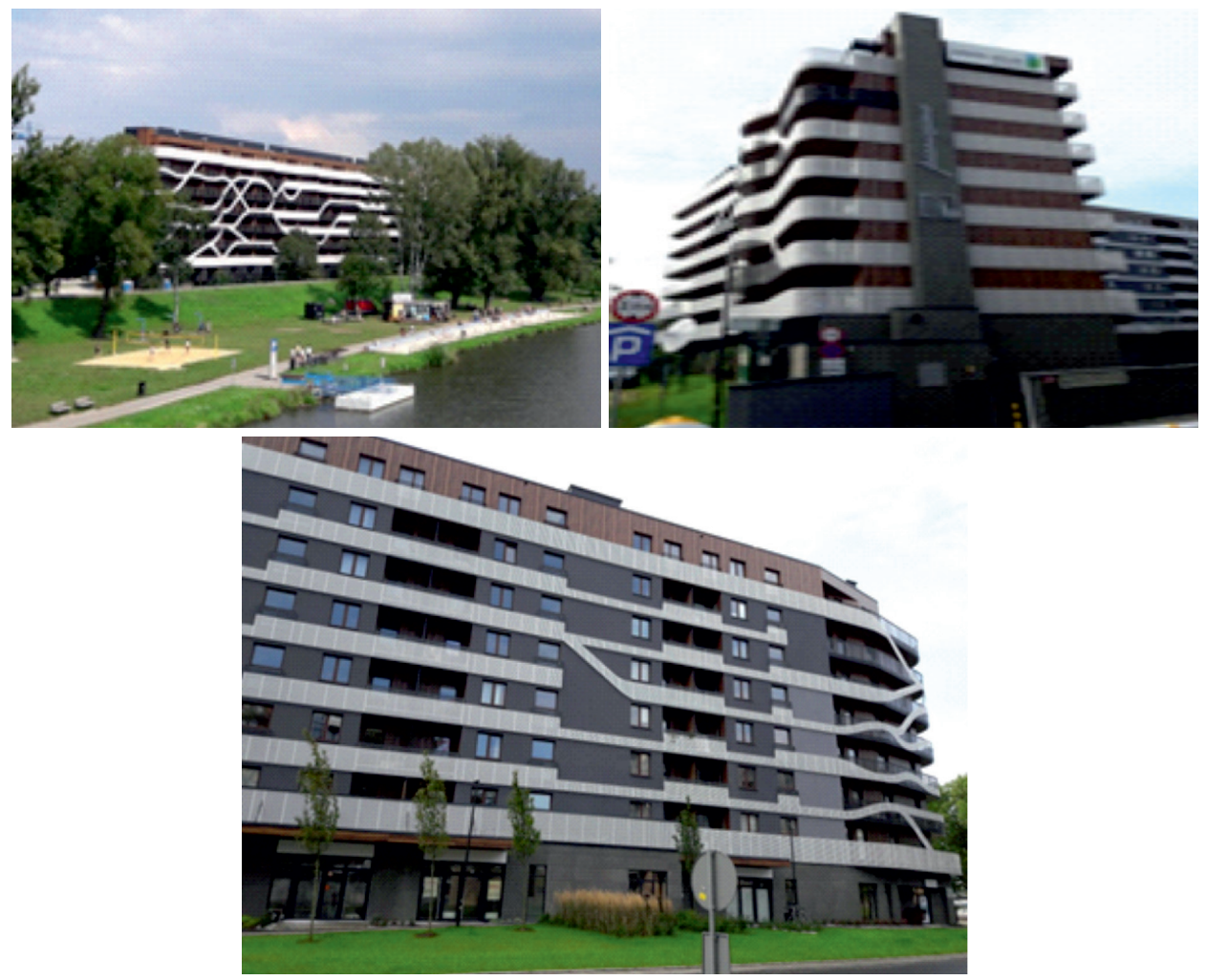

Fot. 19. Apartamentowiec „Pianissimo”, ul. Stachowskiego 4 Źródło: fot. M. Sobczyński 


\section{Przemiany użytkowania ziemi badanego terenu w okresie XIX-XXI w.}

Badanie zmian w zakresie użytkowania ziemi badanego fragmentu południowej części dzielnicy Grzegórzki w Krakowie, stanowiącego blok urbanistyczny o powierzchni $151750 \mathrm{~m}^{2}$, ograniczonego ulicami Kotlarską, Grzegórzecką, Zieleniewskiego i brzegiem Wisły, prowadzona była w oparciu o analizę historycznych planów i map metodą retrospektywną, analizę zdjęć lotniczych i satelitarnych oraz dwukrotne kartowanie form użytkowania ziemi w terenie.

Badania przeprowadzono $\mathrm{w}$ oparciu o podkład mapy geodezyjnej w skali 1:1000, posługując się metodą kartowania użytkowania przestrzeni miejskiej w oparciu o klasyfikację zaproponowaną przez Karola Bromka, wypracowaną w krakowskim ośrodku geograficznym od połowy lat 50. XX w. (Bromek 1955; Bromek 1966; Bromek, Malinowska, Mydel 1971; Bromek, Mydel 1972; Luchter 1990: 13-16).

Po raz pierwszy kartowanie użytkowania ziemi w terenie przeprowadzono w badanym bloku urbanistycznym w latach 1974-1975 ukazując szczegółowy stan użytkowania na dzień 13 listopada 1975 roku (Sobczyński 1976). Badania te powtórzono w końcu września 2019 roku, jednak jako podkład wykorzystano aktualną mapę geodezyjną miasta Krakowa (Mapa geodezyjna... 2019) i aktualne zdjęcie satelitarne (Ortofotomapa... 2019). Wykorzystano cezury czasowe ortofotomapy dla lat 1996, 2003, 2006, 2019 uzupełnione inwentaryzacją fotograficzną badanej przestrzeni miejskiej.

Analiza starych map i planów okolic Krakowa (przed 1 kwietnia 1910 roku badany obszar nie był włączony administracyjnie do miasta) nie pozwala na dokładne pomiary użytkowania ziemi. Na najstarszych mapach z XVII-XVIII w. rysunek jest schematyczny, skala mało precyzyjna, a standardowe sygnatury, np. zabudowań nie pozwalają na identyfikację rzeczywistej powierzchni poszczególnych budynków. Mapy te odwzorowują przede wszystkim układ dróg, a XIX-wieczne także rozmieszczenie fortyfikacji krakowskiej twierdzy i lokalizację pojedynczych zabudowań wiejskich Grzegórzek i Piasków, stawy oraz przebieg koryta Wisły i Prądnika. Da się z nich odczytać jedynie dominującą formę użytkowania ziemi - w 95\% rolniczą i to w mniejszej części pod uprawami, a przeważnie jako pastwiska, zalewane okresowo przez Wisłę. Stan taki utrzymał się zasadniczo do momentu lokalizacji Zakładów Zieleniewskiego w 1906 roku, a nawet nieco dłużej na pozostałym obszarze badanego bloku.

Dopiero niektóre plany z przełomu XIX i XX wieku pozwalają na określenie rzeczywistych rozmiarów pewnych użytków, zasadniczo jedynie zabudowy oraz działek miejskich przy ul. Kotlarskiej i działki przemysłowej Zakładów Zieleniewskiego przy ul. Grzegórzeckiej 69-71. Plany te dobrze ukazują przemiany 
w zakresie układu dróg wokół badanego obszaru, ale nie pozwalają określić precyzyjnie powierzchni zajmowanej przez nie.

Mapy topograficzne i plany miasta z lat 30. XX wieku nadal nie pozwalają ocenić powierzchni zajmowanych przez inne formy użytkowania ziemi niż zabudowa i użytkowanie przemysłowe. Dopiero niektóre wojenne plany, w szczególności plan z 1944 roku w skali 1:10000, o charakterze informacji poufnej, pozwala na nieco bardziej zróżnicowane pomiary struktury użytkowania ziemi (Krakau 1944).

W 1944 roku zabudowa zajmowała na badanym obszarze $26560,5 \mathrm{~m}^{2}$, czyli stanowiła $17,5 \%$ ogółu powierzchni bloku.

W praktyce zatem do precyzyjnego porównania zmian, które zaszły w użytkowaniu przestrzeni miejskiej badanego bloku urbanistycznego południowych Grzegórzek posłużyły jedynie zdjęcia użytkowania ziemi wykonane w 1975 i 2019 roku, a dynamikę tych zmian można było prześledzić poprzez analizę ortofotomapy z lat 1996-2019.

W 1975 roku badany blok urbanistyczny o powierzchni $151750 \mathrm{~m}^{2}$ (czyli 15,17 ha), zamieszkiwało jedynie 465 osób, co dawało niezwykle niską jak na obszar miasta gęstość zaludnienia - 31 osób/ha (Sobczyński 1976: 68). Dowodziło to wybitnie przemysłowego charakteru badanej przestrzeni, w której domy mieszkalne znajdowały się wyłącznie przy ul. Kotlarskiej. Obszar zabudowany w badanym bloku zajmował $41458 \mathrm{~m}^{2}$, co stanowiło $27,3 \%$ powierzchni badanego obszaru (Sobczyński 1976: 72). Powierzchnia ogólna domów (stanowiąca iloczyn powierzchni budynku i liczby jego kondygnacji), wynosiła $61567 \mathrm{~m}^{2}$, a zatem wskaźnik intensywności zabudowy (iloraz ogólnej powierzchni zabudowy do powierzchni badanego obszaru) był dość niski i wynosił 0,41 (Sobczyński 1976: 73).

W 1996 roku w badanym bloku urbanistycznym pod zabudową pozostawało $39573,2 \mathrm{~m}^{2}$, czyli 26,1\% (ryc. 6).

Jak wykazała analiza dla roku 2019 po całkowitym przekształceniu badanego bloku urbanistycznego zabudowane było $26487 \mathrm{~m}^{2}$ badanego obszaru, czyli 17,45\% ogółu badanego terenu, a zatem podobnie jak w okresie drugiej wojny światowej (ryc. 7). Szczegółowo istniejący stan zabudowy badanego bloku urbanistycznego, jej powierzchni użytkowej, materiału budowlanego i struktury funkcjonalnej przedstawia tabela 1 .

Nominalnie, zatem powierzchnia obszaru zabudowanego znacząco zmalała, ale de facto rozległe jednokondygnacyjne hale produkcyjne zastąpiono 7 wysokimi na 6-10 pięter apartamentowcami, zajmującymi jednak mniej przestrzeni zabudowanej, dzięki czemu pojawiła się w bloku zieleń otaczająca domy mieszkalne. Niewielkie zmiany nastąpiły natomiast w zabudowie wschodniej pierzei ul. Kotlarskiej, gdzie na wolnych działkach wzniesiono trzy nowe budynki 


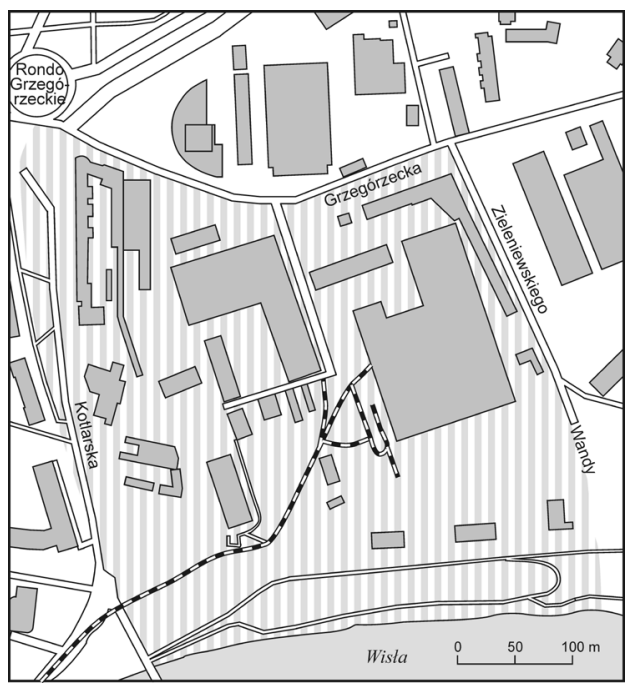

Ryc. 6. Zabudowa badanego obszaru południowych Grzegórzek w 1996 r.

Źródło: Ortofotomapa... (1996)

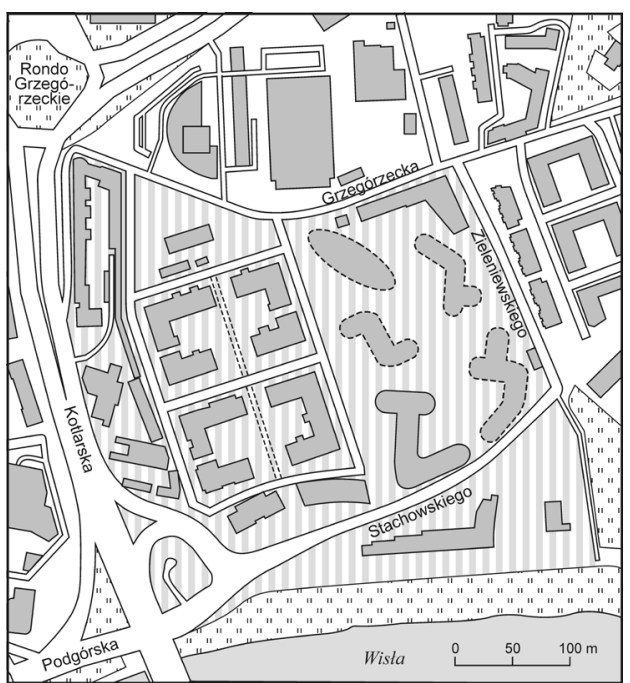

Ryc. 7. Zabudowa badanego obszaru południowych Grzegórzek w 2019 r. Źródło: Ortofotomapa... (2019)

mieszkalne, w tym jeden 8-piętrowy. Powierzchnia ogólna budynków w 2019 roku wynosiła aż $168934 \mathrm{~m}^{2}$, czyli ponad 100 tys. m² więcej niż w 1975 roku, a wskaźnik intensywności zabudowy osiągnął wartość 1,1, jest zatem prawie trzykrotnie wyższy niż w 1975 roku. Największe zmiany zaszły w układzie komunikacyjnym. Ulicę Kotlarską przekształcono w czteropasmową drogę szybkiego ruchu, jako najbliższe Staremu Miastu od wschodu szybkie połączenie północ-południe, wzdłuż którego lokuje się nowe centrum administracyjne miasta i województwa. Budynki przy ul. Kotlarskiej zostały odseparowane od jezdni dźwiękochłonnymi panelami. Ulica Grzegórzecka na odcinku przebiegającym w badanym obszarze pozostała zaślepiona od strony Ronda Kotlarskiego, a ruch skierowano nowym ciągiem komunikacyjnym od Alei Pokoju, ulicami Szolc-Rogozińskiego, Zieleniewskiego (dawniej Wandy) i nowo wytyczoną ul. Stachowskiego, dochodzącą łukiem do węzła komunikacyjnego na północnym przyczółku Mostu Kotlarskiego, przechodzącą w starą ulicę Podgórską. Wnętrze dawnych Zakładów Zieleniewskiego, obecnie zajmowane przez zabudowę apartamentową, poprzecinano nowymi dojazdowymi i pieszymi ciągami komunikacyjnymi (jest to obszar zamknięty, tylko do użytku mieszkańców) otoczonymi zielenią i obiektami rekreacji sportowej i wypoczynkowej (ryc. 8). 
Tabela 1. Zabudowa badanego obszaru południowych Grzegórzek w 2019 r.

\begin{tabular}{|c|c|c|c|c|c|c|c|}
\hline Adres & $\begin{array}{c}\mathrm{Nr} \\
\text { budynku }\end{array}$ & $\begin{array}{c}\text { Liczba } \\
\text { kon- } \\
\text { dygna- } \\
\text { cji } \\
\end{array}$ & $\begin{array}{l}\text { Pow. } \\
\mathrm{w} \mathrm{m}^{2}\end{array}$ & $\begin{array}{l}\text { Pow. } \\
\text { ogólna } \\
\mathrm{w} \mathrm{m}^{2}\end{array}$ & $\begin{array}{c}\text { Mate- } \\
\text { riał }\end{array}$ & $\begin{array}{l}\text { Funk- } \\
\text { cja }\end{array}$ & Instytucje \\
\hline 1 & 2 & 3 & 4 & 5 & 6 & 7 & 8 \\
\hline Kotlarska 2 & $103 / 1.1$ & 5 & 335 & 1675 & $\mathrm{c}$ & $\mathrm{m} / \mathrm{u}$ & $\begin{array}{l}\text { Stomatologia, } \\
\text { księgarnia }\end{array}$ \\
\hline Kotlarska 4 & $102 / 1.1$ & 5 & 200 & 1000 & $\mathrm{c}$ & $\mathrm{m}$ & Kosmetyka \\
\hline Kotlarska 6 & 101/1.1 & 5 & 280 & 1400 & $\mathrm{c}$ & $\mathrm{m} / \mathrm{u}$ & Hostel Attic \\
\hline Kotlarska 8 & $100 / 1.1$ & 5 & 235 & 1175 & $\mathrm{c}$ & $\mathrm{m}$ & \\
\hline Kotlarska 10 & $99 / 3.1$ & 5 & 320 & 1600 & $\mathrm{c}$ & $\mathrm{m}$ & $\begin{array}{c}\text { Centrum Edukacji } \\
\text { Mathrix, } \\
\text { Rationalsewer }\end{array}$ \\
\hline Kotlarska 14 & $98 / 1.1$ & 4 & 159 & 636 & $\mathrm{c}$ & $\mathrm{m}$ & \\
\hline Kotlarska 16 & $97 / 3.1$ & 4 & 215 & 860 & $\mathrm{c}$ & $\mathrm{m} / \mathrm{u}$ & Sklep Snajper \\
\hline Kotlarska 18 & $97 / 4.1$ & 8 & 364 & 2912 & $\mathrm{p}$ & $\mathrm{m} / \mathrm{b}$ & $\begin{array}{c}\text { Stowarzyszenie } \\
\text { Niewidomych } \\
\text { „Kos” }\end{array}$ \\
\hline \multirow{15}{*}{ Kotlarska 34} & $181 / 7.1$ & 1 & 96 & 96 & $\mathrm{c}$ & $\mathrm{g}$ & \\
\hline & $181 / 7.2$ & 1 & 654 & 654 & $\mathrm{c}$ & $\mathrm{mg}$ & \\
\hline & $181 / 7.3$ & 1 & 43 & 43 & $\mathrm{c}$ & g & \\
\hline & $181 / 8.3$ & 1 & 69 & 69 & $\mathrm{c}$ & $\mathrm{u}$ & \\
\hline & $181 / 8.1$ & 1 & 188 & 188 & $\mathrm{c}$ & $\mathrm{u}$ & \\
\hline & $181 / 8.2$ & 1 & 101 & 101 & $\mathrm{c}$ & $\mathrm{u}$ & \\
\hline & $183 / 2.1$ & 1 & 265 & 265 & $\mathrm{c}$ & $\mathrm{mg}$ & $\begin{array}{c}\text { Remat/Bolix } \\
\text { Magazyn }\end{array}$ \\
\hline & $182 / 3.2$ & 1 & 497 & 497 & $\mathrm{k}$ & $\mathrm{u}$ & $\begin{array}{c}\text { Albero - meble } \\
\text { prochownia }\end{array}$ \\
\hline & $182 / 3.5$ & 1 & 57 & 57 & $\mathrm{c}$ & $\mathrm{u}$ & \\
\hline & $182 / 3.4$ & 1 & 63 & 63 & $\mathrm{c}$ & $\mathrm{u}$ & \\
\hline & $182 / 3.8$ & 1 & 22 & 22 & $\mathrm{c}$ & $\mathrm{u}$ & \\
\hline & $182 / 3.7$ & 1 & 37 & 37 & $\mathrm{c}$ & $\mathrm{u}$ & \\
\hline & $182 / 3.3$ & 1 & 482 & 482 & $\mathrm{c}$ & $\mathrm{u}$ & $\begin{array}{c}\text { Edis Auto Service } \\
\text { warsztat }\end{array}$ \\
\hline & $182 / 3.1$ & 2 & 783 & 1566 & $\mathrm{c}$ & $\mathrm{u}$ & $\begin{array}{c}\text { Wienkra - instalacje } \\
\text { grzewcze }\end{array}$ \\
\hline & $182 / 3.6$ & 1 & 54 & 54 & $\mathrm{c}$ & $\mathrm{u}$ & Pracownia witraży \\
\hline
\end{tabular}




\begin{tabular}{|c|c|c|c|c|c|c|c|}
\hline 1 & 2 & 3 & 4 & 5 & 6 & 7 & 8 \\
\hline \multirow[t]{2}{*}{ Grzegórzecka 67} & $181 / 6.1$ & 6 & 324 & 1944 & $\mathrm{p}$ & $\mathrm{m} / \mathrm{u}$ & \begin{tabular}{|c|} 
Spółdzielnia „Pszcze- \\
larz”, sklep Żabka
\end{tabular} \\
\hline & $181 / 6.2$ & 1 & 125 & 125 & $\mathrm{c}$ & $\mathrm{u}$ & Lokal usługowy pusty \\
\hline Grzegórzecka 67a & $180 / 16.1$ & 2 & 502 & 1004 & $\mathrm{c}$ & $\mathrm{u}$ & $\begin{array}{l}\text { Restauracja } \\
\text { Phong Hai }\end{array}$ \\
\hline Grzegórzecka 67b & $298 / 19.1$ & 3 & 187 & 561 & $\mathrm{c}$ & $\mathrm{u}$ & Biuro Inter-Bud \\
\hline Grzegórzecka $67 \mathrm{c}$ & $298 / 4.1$ & 9 & 2654 & 23886 & $\mathrm{p}$ & $\mathrm{m} / \mathrm{u}$ & $\begin{array}{c}\text { Wiślane Tarasy bl. 3, } \\
\text { Żłobek Tosia, Gastro- } \\
\text { medica, Medicina, } \\
\text { Komineczek, Ego } \\
\text { Kosmetyka, Intima } \\
\text { Clinic, SCM, sklep } \\
\text { Żabka, apteka Hygie- } \\
\text { ia, Centrum Zdrowia } \\
\end{array}$ \\
\hline Grzegórzecka $67 \mathrm{~h}$ & $298 / 5.1$ & 9 & 2259 & 20331 & $\mathrm{p}$ & $\mathrm{m} / \mathrm{u}$ & $\begin{array}{c}\text { Wiślane Tarasy bl. 6, } \\
\text { sklep Parmezan }\end{array}$ \\
\hline Grzegórzecka $67 \mathrm{~d}$ & $298 / 6.1$ & 8 & 2499 & 19992 & $\mathrm{p}$ & $\mathrm{m} / \mathrm{u}$ & $\begin{array}{c}\text { Wiślane Tarasy bl. 2, } \\
\text { fryzjer, kosmetyka; } \\
\text { Biuro sprzedaży } \\
\text { mieszkań WT }\end{array}$ \\
\hline Grzegórzecka $67 \mathrm{~g}$ & $298 / 7.1$ & 8 & 2277 & 18216 & $\mathrm{p}$ & $\mathrm{m}$ & Wiślane Tarasy bl. 5 \\
\hline Grzegórzecka 67e & $298 / 13.1$ & 6 & 1014 & 6084 & $\mathrm{p}$ & $\mathrm{m}$ & Wiślane Tarasy bl. 1 \\
\hline \multirow[t]{2}{*}{ Grzegórzecka $67 \mathrm{f}$} & $298 / 5.1$ & 6 & 1163 & 6978 & $\mathrm{p}$ & $\mathrm{m} / \mathrm{b}$ & $\begin{array}{c}\text { Wiślane Tarasy bl. 4, } \\
\text { Biuro Projektowe } \\
\text { Home Concept }\end{array}$ \\
\hline & $298 / 12.1$ & 1 & 11 & 11 & $\mathrm{c}$ & $\mathrm{i}$ & - \\
\hline Grzegórzecka 69 & $180 / 13.1$ & 5 & 585 & 2925 & $\mathrm{c}$ & b & $\begin{array}{l}\text { Budynek dyrekcji, } \\
\text { Kancelaria radcowska } \\
\text { In Extesno, Jazz Dan- } \\
\text { ce Center, La Bart - } \\
\text { szkło, Polski Związek } \\
\text { Wędkarski, Balmont }\end{array}$ \\
\hline Grzegórzecka 69a & $302 / 1.1$ & 2 & 90 & 180 & $\mathrm{c}$ & $\mathrm{i}$ & Portiernia \\
\hline \multirow{3}{*}{ Grzegórzecka 69c } & $301 / 2.1$ & 1 & 188 & 188 & $\mathrm{c}$ & $\mathrm{i}$ & - \\
\hline & $411 / 9.1$ & 10 & 2791 & 27910 & $\mathrm{p}$ & $\mathrm{m}$ & $\begin{array}{c}\text { Wiślane Tarasy 2, bl. D, } \\
\text { Hostel Sparrow }\end{array}$ \\
\hline & $411 / 3.1$ & 1 & 113 & 113 & $\mathrm{c}$ & $\mathrm{i}$ & - \\
\hline
\end{tabular}


Tabela 1 (cd.)

\begin{tabular}{|c|c|c|r|r|r|r|c|}
\hline 1 & 2 & 3 & 4 & 5 & 6 & 7 & 8 \\
\hline Grzegórzecka 71 & $180 / 1.1$ & 3 & 1370 & 4110 & $\mathrm{c}$ & $\mathrm{u}$ & Teatr Variété \\
\cline { 2 - 8 } & $302 / 4.1$ & 2 & 124 & 248 & $\mathrm{c}$ & $\mathrm{i}$ & Ruina \\
\hline Stachowskiego 4 & $240 / 3.1$ & 8 & 2282 & 18256 & $\mathrm{p}$ & $\mathrm{m} / \mathrm{u}$ & $\begin{array}{c}\text { Pianissimo, Żabka, } \\
\text { Restauracja } \\
\text { HiPizza\& Sushi }\end{array}$ \\
\hline Zieleniewskiego & $173 / 6.1$ & 1 & 420 & 420 & $\mathrm{c}$ & $\mathrm{i}$ & $\begin{array}{c}\text { Podstacja } \\
\text { energetyczna }\end{array}$ \\
\hline Suma & - & - & 26497 & 168934 & - & - & - \\
\hline
\end{tabular}

Objaśnienia skrótów: materiał: c - cegła, $\mathrm{p}$ - pustak, k - kamień; funkcja: $\mathrm{m}$ - mieszkaniowa; $\mathrm{u}$ - usługowa; b - biurowa, g - garaż; mg - magazyn; i - pozostałe Źródło: oprac. własne w oparciu o Mape geodezyjną Krakowa (2019) i Mapy Google (2019).

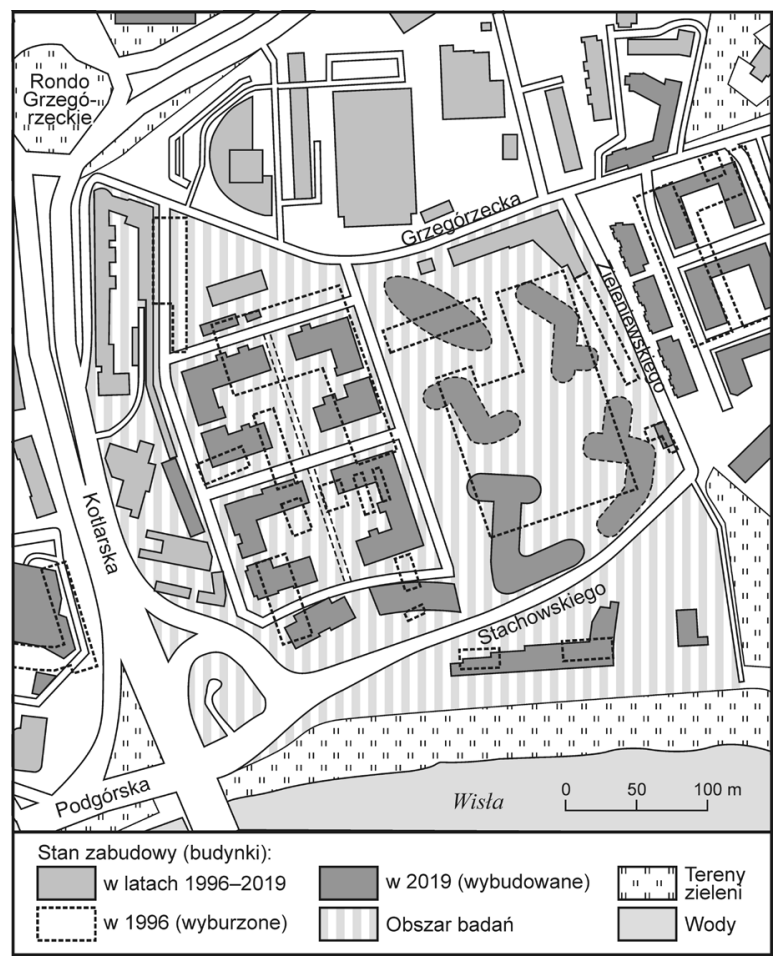

Ryc. 8. Zmiany zabudowy południowej części Grzegórzek w latach 1996-2019

Źródło: oprac. własne 
Rewolucyjne zmiany dotknęły przede wszystkim obszar byłych Zakładów Zieleniewskiego, na którym $\mathrm{z}$ dawnej zabudowy przetrwały tylko wszystkie trzy budynki przy ul. Grzegórzeckiej 69, 69a, 71 (dyrekcja, portiernia i teatr) (fot. 14, 20), jeden budynek w głębi zakładu już nieużytkowany, przeznaczony do rozbiórki wraz z postępem drugiego etapu budowy Wiślanych Tarasów oraz pozostające w ruinie budynki przy ul. Zieleniewskiego i Stachowskiego.
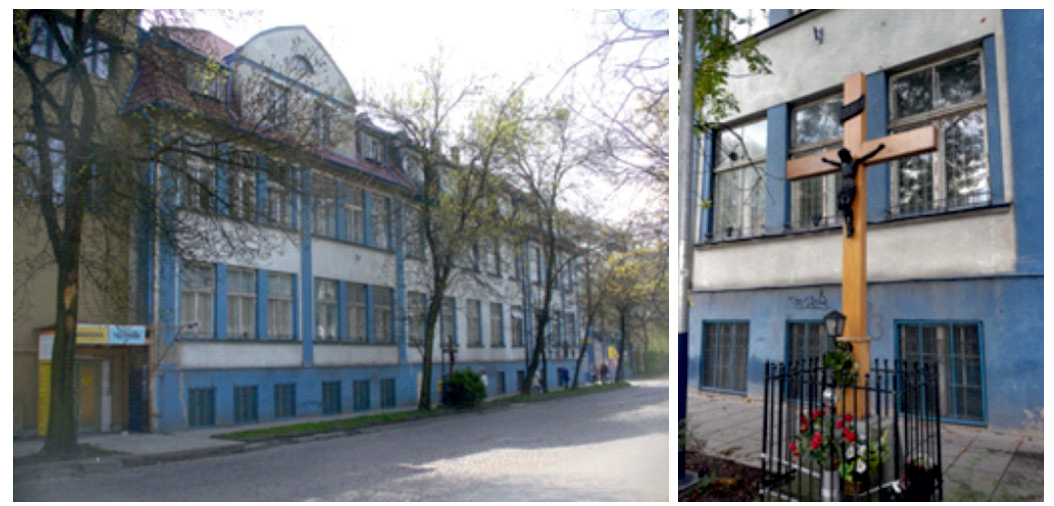

Fot. 20. Budynek byłej dyrekcji Zakładów Zieleniewskiego, ul. Grzegórzecka 69, krzyż postawiono w $1981 \mathrm{r}$.

Źródło: fot. M. Sobczyński

Dopiero po zrujnowaniu większości obiektów wpisano pod nr 1749 na krakowską listę zabytków to, co pozostało po Zakładach Zieleniewskiego (dyrekcję, portiernię) i resztkę jednej hali (fot. 21) oraz gmach byłego kina (nr 1751). Zabytkami są także na badanym obszarze kamienice przy ul. Kotlarskiej 2, 4, 6, 8, 14, 16, Grzegórzeckiej 67 i prochownia przy ul. Kotlarskiej 34.

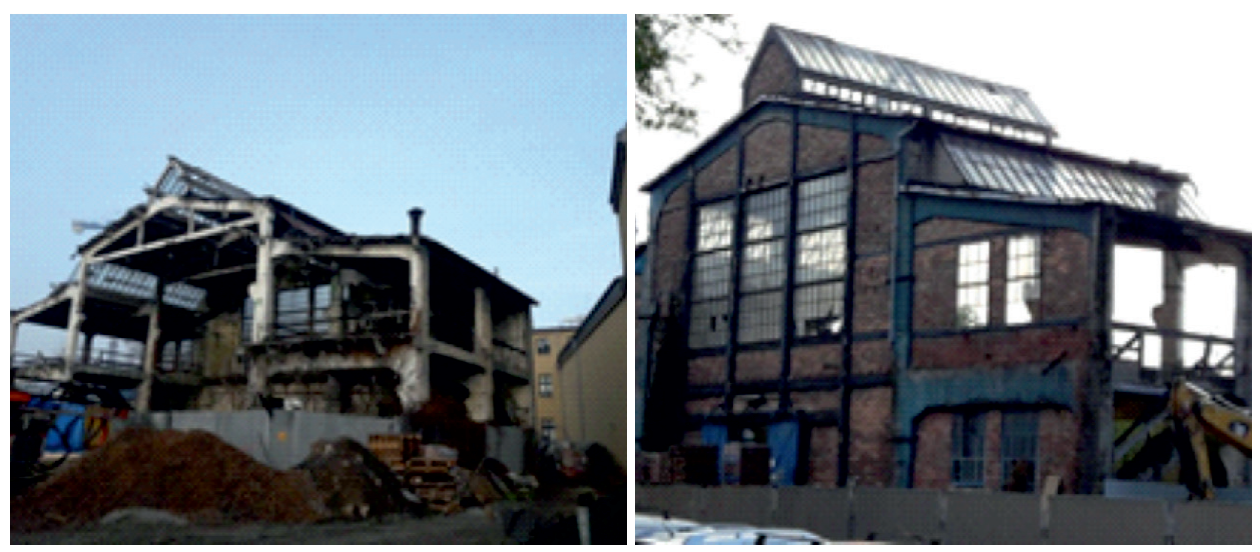



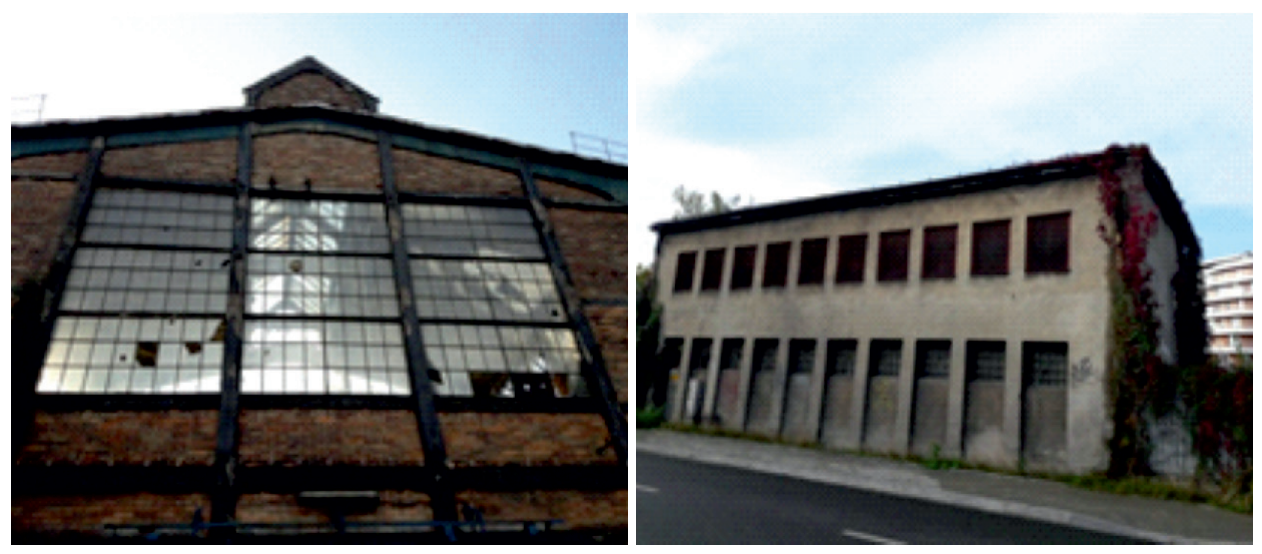

Fot. 21. Ruiny hali maszyn Zakładów Zieleniewskiego i ostatni ocalały nadal eksploatowany budynek (przeznaczony do rozbiórki) (stan październik 2020)

Źródło: fot. M. Sobczyński

Nastąpiła też duża zmiana funkcji pełnionych przez badaną przestrzeń Grzegórzek. Dotychczas zmarginalizowana funkcja mieszkaniowa (poprzednio reprezentowana wyłącznie przy ul. Kotlarskiej) stała się dominującą funkcją badanego obszaru. Dotychczasowa dominanta funkcjonalna tego bloku urbanistycznego - funkcja produkcyjna została niemal całkowicie z niego wyeliminowana (z wyjątkiem drobnego zakładu przy ul. Kotlarskiej 34, produkującego urządzenia klimatyzacyjne). Funkcja usługowa, dotąd incydentalnie występująca (sklepik zakładowy, stołówka, spółdzielnia pszczelarska), znalazła nową lokalizację w parterach apartamentowców (dominacja usług ochrony zdrowia i poprawy urody), ale przy bardzo ograniczonym udziale handlu i edukacji przedszkolnej. Nowym zjawiskiem jest pojawienie się handlu i usług (w tym warsztatów samochodowych) przy ul. Kotlarskiej, w zabudowie kamienicami czynszowymi. Funkcja kultury jest reprezentowana przez ten sam obiekt, były Dom Socjalny Zakładów Zieleniewskiego, niegdyś kino, dziś teatr.

Niewielkie fragmenty badanego obszaru nadal pozostają ugorem poprzemysłowym, jeden $\mathrm{z}$ nich zostanie zapewne wkrótce wyburzony, drugi uznany za najcenniejszy zabytek poprzemysłowy tego obszaru (najstarsza hala produkcji maszyn), został w 90\% zburzony - pozostała zasadniczo tylko ściana północna i niewielki fragment dachu ze świetlikami (fot. 21), ale obowiązkiem inwestora jest zachowanie (odbudowa?) tego obiektu, który jak na razie nie wydaje się być wkomponowany w plan zagospodarowania drugiego etapu rozbudowy „Wiślanych Tarasów". Dysonansem jest już fakt, iż wszystkie budynki tej części inwestycji mają formy owalne, a hala fabryczna jest prostokątna. 


\section{Zakończenie}

Przemiany, które nastąpiły na badanym obszarze poprzemysłowego bloku urbanistycznego położonego w południowej część Grzegórzek w Krakowie, zajmowanego w przeważającej części przez Zakłady Budowy Maszyn i Aparatury L. Zieleniewskiego mają zatem charakter rewolucyjny, zarówno jako przejście na początku XX wieku od przestrzeni ruralnej do przemysłowej, jak i przemiana z początku XXI wieku z ugoru poprzemysłowego do atrakcyjnego architektonicznie prestiżowego osiedla mieszkaniowego. Wpłynęło to na formy zagospodarowania przestrzeni i sposób użytkowania ziemi na badanym obszarze również w wymiarze rewolucyjnym, niekiedy wręcz w proporcjach zero-jedynkowych. Osiedle „Wiślane Tarasy” złożone z dwóch etapów realizacyjnych jest atrakcyjnym architektonicznie, luksusowym projektem, wskazującym drogę rewitalizacji obszarów poprzemysłowych w miastach postsocjalistycznych przy założeniu niemal całkowitej wymiany substancji.

\section{Literatura}

Bąkowski K., 1911, Dzieje Krakowa, Spółka Wydawnicza Polska, Kraków.

Bąkowski K., 1932, Rozwój gospodarczy Krakowa w ostatnich stu latach, [w:] Kraków w XIX w., Bibljoteka Krakowska, 72, t. 1: 160-180, Towarzystwo Miłośników Historii i Zabytków Krakowa, Kraków.

Bromek K., 1955, Opracowanie szczegółowej mapy użytkowania ziemi dla Krakowa, „Przegląd Geograficzny”, 27(3-4): 589-604.

Bromek K., 1966, Użytkowanie ziemi w Krakowie i przylegtych częściach powiatu krakowskiego około 1966 roku, ,Zeszyty Naukowe U. Prace Geograficzne”, 14, Kraków.

Bromek K., Malinowska D., Mydel R., 1971, Metoda szczegółowego zdjęcia użytkowania terenów miejskich, Sprawozdania z Posiedzeń Komisji Nauk Geograficznych Oddziału PAN w Krakowie, t. I-IV: 205-206.

Bromek K., Mydel R., 1972, Uwagi metodyczne do opracowania szczegótowej mapy użytkowania ziemi przestrzeni miejskiej, „Folia Geographica, ser. Geographica-Oeconomica", 5: 149-159.

Chmiel A., 1932, Ustrój m. Krakowa w XIX w. Działalność prezydentów miasta 18661924, [w:] Kraków w XIX w., Bibljoteka Krakowska, 72, t. 1: 78-159, Towarzystwo Miłośników Historii i Zabytków Krakowa, Kraków.

Chrobaczyński J., 2004, Kraków przed i w 1914 roku, „Dzieje Najnowsze”, 36(3): 63-78.

Dróżdż M., Bradecki J., Majewski T., 1999, Historia polskiego przemystu aparatury chemicznej gazów technicznych, Karty z historii polskiego przemysłu chemicznego, t. 9-10, Stowarzyszenie Inżynierów i Techników Przemysłu Chemicznego, Warszawa-Gliwice.

Encyklopedia Krakowa, 2009, Wydawnictwo Naukowe PWN, Warszawa. 
Figiel S., 1961, Strajk w 1936 r. (dokumenty i wspomnienia), [w:] Zieleniewszczacy. 25-lecie strajku 1936-1961, Zakłady Budowy Maszyn i Aparatury im. Stanisława Szadkowskiego w Krakowie, Kraków: 27-78.

Jasiuk J., 2007, Dynastia Zieleniewskich, „Przegląd Techniczny”, http://arch.przeglad-techniczny.pl/archiwum/index_2007_26.htm (dostęp: 26.10.2019).

Kalkowski J., 1961, Z dziejów Zakładów Zieleniewskiego, [w:] Zieleniewszczacy. 25-lecie strajku 1936-1961, Zakłady Budowy Maszyn i Aparatury im. Stanisława Szadkowskiego w Krakowie, Kraków: 9-26.

Kawecki S., 1927, Opis miasta Krakowa w obrębie okopów w r. 1836, oprac. A. Chmiel, Bibljoteka Krakowska, 65, Towarzystwo Miłośników Historii i Zabytków Krakowa, Kraków.

Luchter B., 1990, Przestrzenne związki użytkowania ziemi w Krakowie, „Dokumentacja Geograficzna", 2-3, IGiPZ PAN, Warszawa.

Nowak J.T., 2017, Wokół ulicy Grzegórzeckiej, Muzeum Historyczne Miasta Krakowa, Kraków.

Paciorek A., 1991, Uruchomienie i upaństwowienie przemystu Krakowa oraz jego przeobrażenia w latach 1945-1949, Prace Monograficzne, Wyższa Szkoła Pedagogiczna im. KEN w Krakowie, Kraków.

Saryusz-Zaleski W., 1930, Dzieje przemystu w b. Galicji 1804-1929 ze szczególnem uwzględnieniem historii rozwoju S.A. L. Zieleniewski i Fitzner-Gamper, Wydawnictwo z okazji 125-letniego jubileuszu, S.A. L. Zieleniewski i Fitzner-Gamper, Kraków.

Sikora L., 1908, Szwedzi i Siedmiogrodzianie w Krakowie od 1655 do 1637 roku, Biblioteka Krakowska, 39, Towarzystwo Miłośników Historii i Zabytków Krakowa, Kraków.

Sobczyński M., 1976, Użytkowanie przestrzeni miejskiej w pd. części XIX dz. kat. M. Krakowa - Grzegórzek, Zakład Geografii Ludności, Osadnictwa i Rolnictwa, Instytut Geografii Uniwersytetu Jagiellońskiego, Kraków (niepublikowany maszynopis).

Stec T., 1961, Zakłady im. Szadkowskiego-dzisiaj, [w:] Zieleniewszczacy. 25-lecie strajku 1936-1961, Zakłady Budowy Maszyn i Aparatury im. Stanisława Szadkowskiego w Krakowie, Kraków: 80-143.

Tobiasz M., 1974, Pierwsze wieki Krakowa, Wojewódzki Ośrodek Informacji Turystycznej, Kraków.

Tomkowicz S., 1926, Ulice i place Krakowa w ciagu dziejów ich nazwy i zmiany postaci, Bibljoteka Krakowska, 63-64, Towarzystwo Miłośników Historii i Zabytków Krakowa, Kraków.

Ważniejsze daty z historii firmy, 2001, [w:] Wyka E., Krzaczyńska B. (red.), Zieleniewscy i ich zakłady 1804-1945, Wystawa 15 XII 2000-25 II 2001, Muzeum Inżynierii Miejskiej, Kraków: 12-31.

Zawistowski J., 2001, Od kuźni do koncernu, [w:] Wyka E., Krzaczyńska B. (red.), Zieleniewscy $i$ ich zakłady 1804-1945, Wystawa 15 XII 2000-25 II 2001, Muzeum Inżynierii Miejskiej, Kraków: 7-11.

Zawistowski J. (red.), 1979, Zakład Budowy Maszyn i Aparatury im. Stanisława Szadkowskiego w Krakowie 1804-1979, Warszawa-Kraków. 


\section{Źródła kartograficzne}

Dahlberg Jönson E., 1696, Plan oblężenia Krakowa przez wojska szwedzkie, [w:] Pufendorf S., De rebus a Carolo Gustavo Sueciae Rege gestis commentrariorum libri septem elegantissimi tabulis aeneis exornati cum triplici Indie, Nürnberg.

Krakau, 1944, 1:10000, Der Stadthauptmann der Stadt Krakau Stadtmessungsamt, Nur für den Dienstgebrauch, lipiec, Krakau.

Mapa geodezyjna Krakowa, 2019, Małopolska Infrastruktura Informacji Przestrzennej, https://miip.geomalopolska.pl/imap/\#gpmap=gp15 (dostęp: 4.11.2019).

Mapy Google, 2019, https://www.google.com/maps/ (dostęp: 7.11.2019).

Ortofotomapa m. Krakowa, 2019, Małopolska Infrastruktura Informacji Przestrzennej, https://miip.geomalopolska.pl/imap/\#gpmap=gp0 (dostęp: 4.11.2019).

Plan Ogólny Zagospodarowania Przestrzennego Krakowa, 1977, Urząd Miasta Krakowa, http://planowanie.um.krakow.pl/bppzoom/index.php?ID=1 (dostęp: 2.11.2019).

Plan sytuacyjny budynku administracyjnego firmy L. Zieleniewski Tow. Akc. w Krakowie, 1911, 1:1 000, Edmund Zieleniewski, Archiwum Narodowe w Krakowie, zespół archiwalny: Zakład instalacyjny Adam Bieniarz w Krakowie, Plany c.o., wod.-kan., budynków administracyjnych i fabrycznych - Kraków, ul. Grzegórzecka 69-71 (Firma Zieleniewskiego), sygn. 198.

Plan sytuacyjny fabryki L. Zieleniewski i Fitzner-Gamper S.A.w Krakowie, 1926, 1:500, Archiwum Narodowe w Krakowie, zespół archiwalny: Zakład instalacyjny Adam Bieniarz w Krakowie, Plany c.o., wod.-kan., budynków administracyjnych i fabrycznych - Kraków, ul. Grzegórzecka 69-71 (Firma Zieleniewskiego), sygn. 198.

Plan sytuacyjny zabudowań Zieleniewski-Fitzner-Gamper S.A. Kraków-Grzegórzki, 1941, 1:1000, Archiwum Narodowe w Krakowie, zespół archiwalny: Zakład instalacyjny Adam Bieniarz w Krakowie, Plany c.o., wod.-kan., budynków administracyjnych i fabrycznych - Kraków, ul. Grzegórzecka 69-71 (Firma Zieleniewskiego), sygn. 198.

Śniadecki J., Radwański F., 1785, Plan miasta Krakowa z przedmieściami (tzw. plan kottątajowski), 1:3000, Kraków.

Wojkowski J., 2019, Cartographia Cracoviana: Kraków i okolice na dawnych mapach, Dawne Mapy Krakowa, Uniwersytet Rolniczy w Krakowie, Wydział Inżynierii Środowiska i Geodezji, https://dawnemapykrakowa.pl/ (dostęp: 5.11.2019).

\section{Źródla archiwalne}

Archiwum Narodowe w Krakowie. Archiwum Planów Budownictwa Miejskiego w Krakowie, Zespół ul. Grzegórzecka 69/71, sygn. F. 297.

Archiwum Narodowe w Krakowie. Archiwum Planów Budownictwa Miejskiego w Krakowie, Zespół Zakład Instalacyjny Adam Bieniarz w Krakowie. Fabryka Zieleniewski, ul. Grzegórzecka 69/71, sygn. 29/1408/198.

Archiwum Narodowe w Krakowie. Archiwum Planów Budownictwa Miejskiego w Krakowie. Zespół Przedsiębiorstwo Budowy inż. Jerzy Struszkiewicz i s-ka, Kraków. Plan 
dobudowy 2 pięter, budynku administracyjnego dla Zjednoczonych Fabryk Maszyn-Kotłów i Wagonów L. Zieleniewski i Fitzner-Gamper S.A. w Krakowie.

\title{
Netografia
}

Gminna ewidencja zabytków, 2019, Kraków, https://www.bip.krakow.pl (dostęp: 7.11.2019).

Kraków Wiślane Tarasy 2.0, 2017, Projekt Inwestor, https://www.projektinwestor.pl/aktualnosc/krakow-wislane-tarasy-2-0-nowy-projekt-w-centrum (dostęp: 5.11.2019).

Muzeum Historyczne Miasta Krakowa, https://www.radiokrakow.pl/audycje/pod-lupa/ pod-lupa-grzegorzki/ (dostęp: 1.11. 2019).

Narodowe Archiwum Cyfrowe, https://audiovis.nac.gov.pl/obraz/60786:1/ (dostęp: 1.11.2019).

Pianissimo, 2019, Green House Development, https://www.greenhousedevelopment.pl/ pianissimo-kopia (dostęp: 4.11.2019).

Wiślane Tarasy, 2014, Grupa Inter-Bud, http://www.wislanetarasy.com.pl/wislane-tarasy-mieszkania-w-budowie-budynek-4 (dostęp: 4.11.2019).

Wiślane Tarasy 2.0, 2019, Grupa Inter-Bud, https://wislanetarasy2.pl/ (dostęp: 4.11.2019).

\section{Changes in the development of industrial space in the southern part of the $19^{\text {th }}$ cadastral district of Cracow-Grzegórzki in the twentieth and twenty-first centuries on the example of Ludwik Zieleniewski's machinery plant}

\begin{abstract}
The chapter presents the results of field research carried out in the industrialized area of the southern fragment of the $19^{\text {th }}$ cadastral district of Cracow (Grzegórzki), in an urban block delimited by today's streets: Grzegórzecka, Kotlarska and Zieleniewskiego and the Vistula embankment. Changes in the development of space will be shown, first in suburban areas, and from the first decade of the $20^{\text {th }}$ century already in the urban area developed by the metal and machine industry plants of the brothers Ludwik and Edmund Zieleniewski, one of the oldest factory in this industry in Poland.

To investigate the changes, a detailed field mapping of land use was used, made with the method proposed by the team of Karol Bromek (Bromek, Malinowska, Mydel 1971) on a 1:1000 scale, carried out twice along 44 years period (summer-autumn 1975 and autumn 2019) (Sobczyński 1976). The mapping in the area was supplemented by the analysis of the cartographic material (topographic maps, aerial photos, orthophotomap) both from the pre-investment period (the end of the $19^{\text {th }}$ century) and from the caesuras determined by successive stages of changes in the studied space in the period before the first mapping and between both mapping (1975-1999).

From the end of the $19^{\text {th }}$ century, there was an evolution in the use of the studied area of Cracow from agricultural, through industrial and transport to residential and recreational. The political transformations of Poland after 1989 were not conducive to the existence
\end{abstract}


of the heavy machine industry and the plants were gradually closed down. The changes that took place in the study area are revolutionary, both as a transition at the beginning of the $20^{\text {th }}$ century from rural to industrial space and a transformation at the beginning of the $21^{\text {st }}$ century from post-industrial fallow land to an architecturally attractive and prestigious housing estate. The changes made affected the forms of spatial development and land use in the studied area, also in a revolutionary dimension.

Keywords: Cracow, Grzegórzki, Zieleniewski’s plant, urban land use, revitalization of post-industrial areas.

Prof. dr hab. Marek Sobczyński

Uniwersytet Łódzki

Wydział Nauk Geograficznych

Katedra Geografii Politycznej, Historycznej i Studiów Regionalnych

e-mail: marek.sobczynski@geo.uni.lodz.pl

(D) https://orcid.org/0000-0003-1066-3687 